\title{
INDEPENDENT WATER VOLE (MIMOMYS SAVINI, ARVICOLA: RODENTIA, MAMMALIA) LINEAGES IN ITALY AND CENTRAL EUROPE
}

\author{
FEDERICO MASINII', LUTZ CHRISTIAN MAUL 2, ${ }^{*}$, LAURA ABBAZZI $^{3}$, DARIA PETRUSO ${ }^{1}$, ANDREA SAVORELLI ${ }^{3}$ \\ 1 Università di Palermo, Dipartimento di Geologia e Geodesia, Via Archirafi 18, I-90134 Palermo, Italy; \\ e-mail: federico.masini@unipa.it, dariapetruso@libero.it. \\ 2 Senckenberg Research Station of Quaternary Palaeontology Weimar, Am Jakobskirchhof 4, D-99423 Weimar, Germany; \\ e-mail: Imaul@senckenberg.de. \\ ${ }^{3}$ Università di Firenze, Dipartimento di Scienze della Terra, Via G. La Pira 4, I-50121 Firenze, Italy; \\ e-mails: labbazzi@geo.unifi.it, andrea_savorelli@yahoo.it. \\ * corresponding author
}

Masini, F., Maul, L. C., Abbazzi, L., Petruso, D., Savorelli, A. (2020): Independent water vole (Mimomys savini, Arvicola: Rodentia, Mammalia) lineages in Italy and Central Europe. - Fossil Imprint, 76(1): 59-83, Praha. ISSN 2533-4050 (print), ISSN 2533-4069 (on-line).

\begin{abstract}
Water voles are important key fossils of the Quaternary. Given their wide distribution, regional differences were expected to exist in different areas. Early hints on possible independent evolutionary trends of water voles in Italy came from palaeontology and specifically from the comparison of enamel differentiation (SDQ value) of the first lower molars between specimens from Italy and Germany. The data available at that time indicated that in the early Middle Pleistocene there were only minor enamel differences between first lower molars of water voles from these two geographical regions, whereas from the late Middle Pleistocene onwards, two lineages were clearly distinguished. Examination of mitochondrial DNA of extant Arvicola populations from across Europe by Wust-Saucy led to a similar conclusion that Arvicola populations from the Italian Peninsula had undergone independent evolution during the last 0.2 million years.

The inclusion of new fossil and extant Arvicola samples from Italy and Central Europe, together with the examination of additional morphological parameters of the occlusal surface (so-called van der Meulen indexes), have provided further support for the proposed evolutionary pattern. The combined analysis of length, SDQ and A/L index reveal a certain degree of intercorrelation and indicate an essentially continuous evolutionary trend. However, variations are discernible, related to the age and geographical origins of the samples, and become more clearly seen at least since the beginning of the Late Pleistocene. Italian samples have a characteristic tendency to grow larger, elongate the anteroconid, and have less derived SDQ. This corroborates the suggestion that Italian water voles underwent an evolutionary history distinct from that of their Central European counterparts. The differences in morphology may be related to a combination of etho-/ecological (aquatic or terrestrial habits) and palaeobiogeographical factors.
\end{abstract}

Key words: water voles, first molars, Europe, evolution, Pleistocene, morphometrics

Received: June 6, 2019 | Accepted: March 21, 2020 | Issued: November 9, 2020

\section{Introduction}

Extant water voles are members of the genus Arvicola, which includes four species: Arvicola amphibius (LinnaEus, 1758) (=A. terrestris (LinNAEUs, 1758), as it was commonly known a few years ago, was recognised to be a junior synonym - see Wilson and Reeder 2005), which includes European, Siberian, and Anatolian lineages (Kryštufek 2017a), A. italicus SAVI, 1838 (on the Italian Peninsula; Castiglia et al. 2016), A. monticola DE SÉLys-LongChAmps, 1838 (in northern Spain and NW Alp mountains; Kryštufek 2017b), and A. sapidus Miller, 1908 (Spain and France;
Kryštufek 2017c). The genus is geographically distributed over most of the Palaearctic, ranging as far west as the Iberian Peninsula to as far east as the Lake Baikal, and as far north as the Polar Sea to as far south as Israel and Iran. The term "water vole" may be somewhat misleading: most Arvicola actually inhabit water bodies (rivers, streams, ponds etc.), but some are fossorial and live far from water. A. sapidus is strictly aquatic, whereas A. monticola is fossorial, and Arvicola amphibius and $A$. italicus include both aquatic and fossorial morphotypes (Kryštufek et al. 2015).

The fairly rich fossil record has provided sufficient evidence to analyse many aspects of the evolution of water 
voles in great detail. These animals are largely represented by molars which occur in hundreds in Eurasian fossil sites. Their very rapid dental evolution, most studied especially through the taxonomically diagnostic first lower molar (m1) makes them key terrestrial taxa with very high stratigraphic value.

Arvicola has rootless molars. Similarly to other Arvicolinae with arhizodont ( $=$ rootless) cheek teeth (Microtus s. 1., Lemmus or Lagurus), the loss of roots in Arvicola is a secondary adaptation achieved through an evolutionary trend of increasing growth rates of the teeth from an ancestral condition of rooted molars. In many European and Asian regions, the ancestor seems to have been Mimomys savini Hinton, 1910. The molars are assumed to have grown so high to leave no space in the jawbone for both crown and roots, thereby causing the suppression of the latter (the root formation was postponed beyond the life span of the animal, see Koenigswald 1982; for a discussion on possible feedback processes see Maul 2001). This evolutionary process is rather common within the mammalian clade.

M. savini and the oldest Arvicola, A. mosbachensis $($ Schmidtgen, 1911$)(=A$. cantianus $($ Hinton, 1910$)=A$. cantiana $($ Hinton, 1910$)=A$. terrestris cantiana $($ Hinton, 1910)) (for a discussion on the taxonomy see Maul et al. 2000) possess $\mathrm{m} 1 \mathrm{~s}$ with similar occlusal patterns, but the tooth is rooted in Mimomys and rootless in Arvicola. An ancestor-successor relationship between the latest $M$. savini and the earliest Arvicola could be supported by the stratigraphic records and areal distribution of the two taxa.
The transition would have occurred in Central Europe presumably between Marine Isotope Stage (MIS) 17 and 15 (Koenigswald and Van Kolfschoten 1996).

The evolution from the primitive Arvicola mosbachensis to the extant $A$. amphibius can be traced by a change in the thickness of the enamel. The evolutionary differentiation of the enamel was first observed by Heller in fossil remains of Arvicola from Mosbach (Heller 1933: 109; “... in the molars of the recent species, the enamel band on the concave side of the salient angles is always thicker than on the convex, and in the teeth of the fossil remains the opposite is usually the case"); similar changes were later observed in the material from Erpfingen (Heller 1958: 58), Süßenborn (Fejfar 1969: 763), and Petersbuch (Koenigswald 1970: 418). Eventually Heinrich (1978) introduced the SDQ (SchmelzbandDifferenzierungs-Quotient) ratio to quantify the degree of enamel change (see section "Compared parameters" for details). This index is a measure of the relative thickness of the enamel walls in the dental triangles of molars, and accounts for a very general evolutionary trend not only in Arvicola but also in other clades of the subfamily Arvicolinae (Hinton 1926, Heinrich 1978, Koenigswald 1980, Heinrich 1982, 1987, 1990b, Van Kolfschoten 1992, Lippi et al. 1998, Martin and Tesakov 1998). Martin (1987: 271-272) introduced the terms "positive differentiation" when concave enamel edges (anterior in lower molars, posterior in upper ones) are thicker than the convex edges (posterior in lower molars, anterior in upper ones), and "negative differentiation" in the opposite case of enamel thickness.

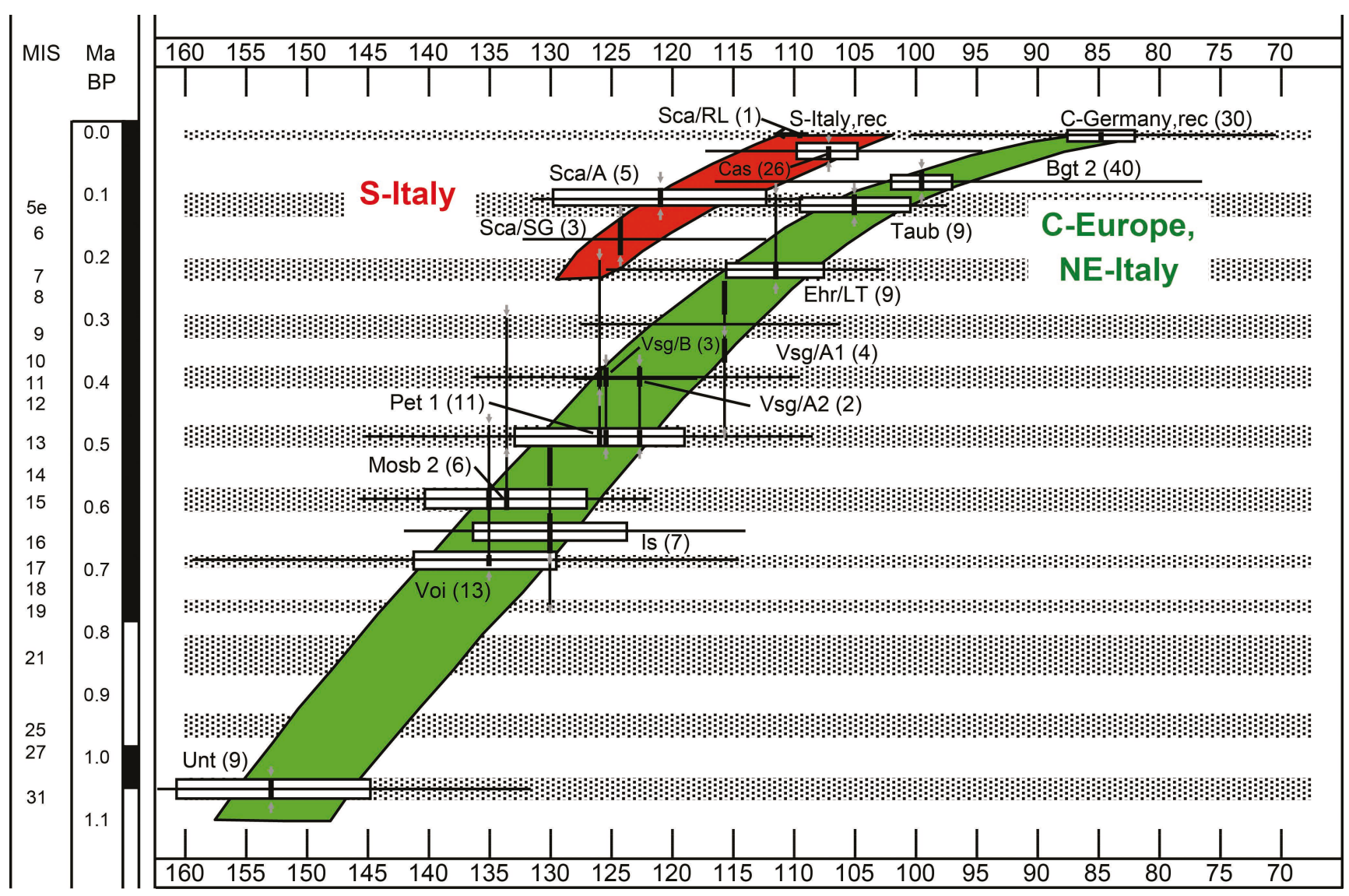

Text-fig. 1. SDQ vs stratigraphic time in samples of Mimomys savini and Arvicola from various Italian and German localities (in brackets: sample size), showing a parallel trend starting from ca. 200 ka. From Maul et al. (1998b: fig. 4), modified. 

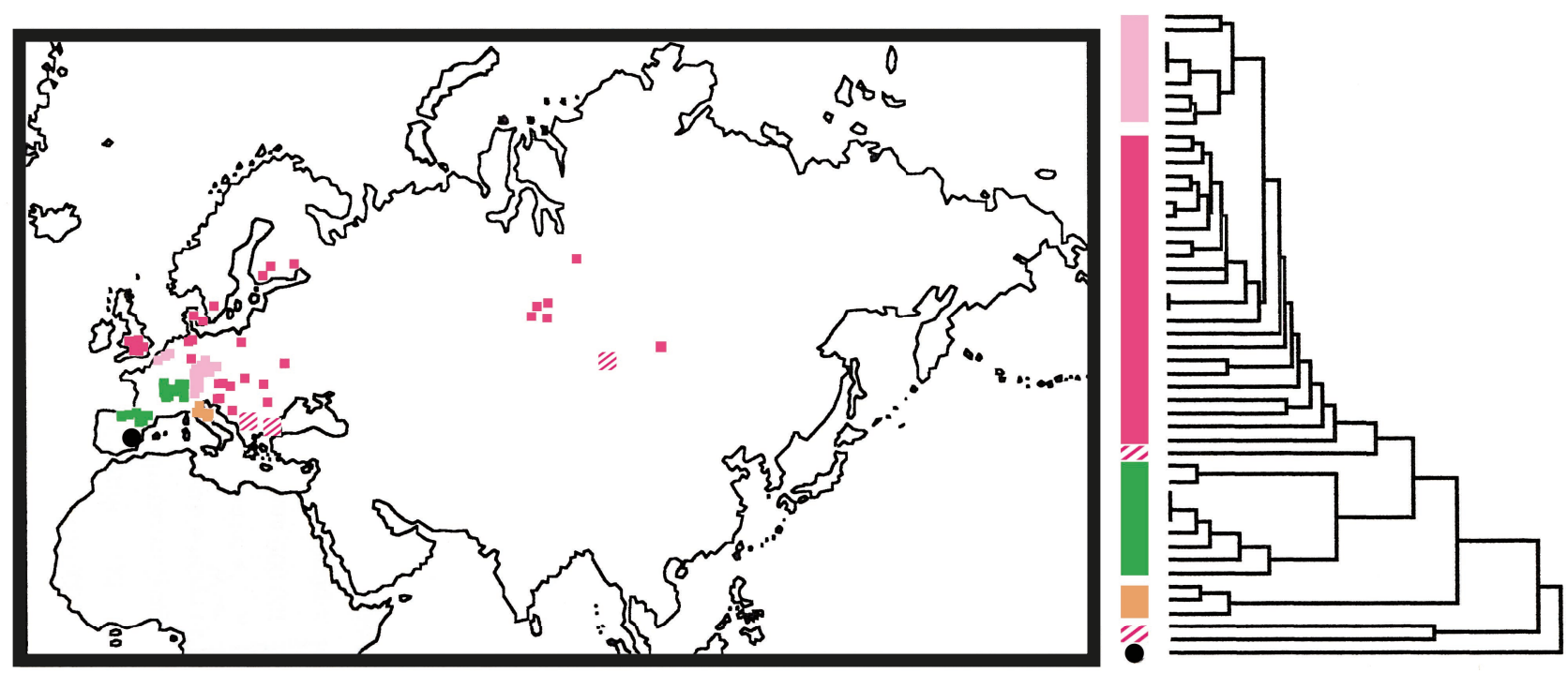

Arvicola amphibius Line A1 $\square$ Arvicola amphibius Line A2
Arvicola amphibius Line F $\square$ Arvicola amphibius Line A2, sub-group
- Arvicola sapidus

Text-fig. 2. Phylogeography based on mitochondrial phylogeny showing several evolutionary lineages of Arvicola and the separation of the Italian lineage of Arvicola, currently A. italicus (lineage A1), from European and Euro-Asiatic groups. From Wust-Saucy (1998: fig. 27), modified.

SDQ values grow lower through time: they range from 150-160 in Mimomys savini to about 80-70 in extant Arvicola amphibius. The lowest values are reached in advanced and most recent species. The transition between A. mosbachensis and A. amphibius is revealed by the SDQ values $(A$. mosbachensis $>100$, A amphibius $<100)$ and occurred in Central Europe during MIS 5 (Heinrich 1978, 1982, 1987, Koenigswald and Heinrich 1999).

The first who found regional and altitudinal influences on the relatively high SDQ values observed in Spanish and Swiss extant populations of Arvicola was Kratochvíl (1981). Röttger (1986, 1987) calculated this ratio (measurement method slightly modified from Heinrich 1978) in extant European and western Asian populations of Arvicola and found relatively high SDQs in the populations living in Spain, Turkey and western Iran.

SDQ values plotted against the estimated ages of Italian and German specimens of water voles show that Italian populations of Arvicola, at least during the last $0.2 \mathrm{Ma}$, maintained relatively less advanced (higher) SDQ values than coeval water voles from Germany (Maul et al. 1998a, b). The Italian water vole can thus be assumed to have undergone geographical differentiation and independent evolution during the late Middle Pleistocene and Late Pleistocene, a time period roughly including the two latest glacial cycles (from Saalian to Holocene) (Text-fig. 1).

Also, Wust-Saucy (1998; reported also in Taberlet et al. 1998), on the basis of molecular phylogeneticalphylogeographical studies on extant Arvicola populations, observed that Italian Arvicola populations had evolved independently from Central European A. amphibius. Wust-Saucy (1998) conducted an extensive analysis of Mitochondrial DNA (cytochrome b gene) of recent Arvicola populations scattered over the entire geographical range of the genus (particularly from large parts of Europe and
Siberia) (see Text-fig. 2). The results of this analysis (Text-fig. 2) showed that Arvicola sapidus from Spain and southern-western France had originally separated from an Arvicola amphibius (= terrestris) clade inhabiting the other geographical regions of distribution of water voles. Worth noting, however, is that the study revealed the occurrence of three distinct evolutionary lineages within this broad A. amphibius group, originally reported as A. terrestris terrestris, A. terrestris scherman and A. terrestris italicus in Taberlet et al. (1998). The Italian Arvicola populations (initially indicated as "South of Alps" by Wust-Saucy 1998) would form a distinct, well-characterised lineage, apparently the first to split from the hypothetical common ancestor of the A. amphibius group (Taberlet et al. 1998: fig. 2).

The consistency between the molecular phylogenetic results and the fossil record prompted a morphologicalstratigraphical study of Italian Arvicola. In the present study, a brief survey of the fossil record of Italian water voles is followed by the presentation of morphometric data of new recent and fossil samples of Arvicola. To better explore the peculiarities of the Italian lineage, it is compared with samples from Central Europe and France. The analysis has also been extended considering further indexes, besides the SDQ already investigated by Maul et al. (1998a, b). This study is an extended version of a poster communicated in 2007 (Masini et al. 2007). It intends to provide a more accurate analysis of the morphological trends of the Italian water vole lineage with the ultimate aim of gaining improved knowledge of the evolutionary patterns of these rodents. In most cases the Italian Late Pleistocene/Holocene specimens will be referred to as "Arvicola amphibius group" pending a clear-cut morphological discrimination from the extant $A$. italicus.

Gerhard Storch - to whom this article is dedicated - was a true multitalented expert on both extant and fossil small mammals. He wrote several "now-by-everybody-cited" basic 
papers on Pleistocene mice (see the G. Storch's bibliography in the introduction of volume 1 of this memorial). He was always very interested and open to discussions on these topics, and was, among others, senior author of the paper in which Arvicola mosbachensis from its type locality was studied in detail (Maul et al. 2000). We are confident that he would have enjoyed discussing with us the topic of the present article.

\section{Water vole record of Italy}

\section{Mimomys savini}

Mimomys savini is known only from Palaearctic Biharian sites. The Biharian biochronological unit is based on the co-occurrence of the genera Microtus and Mimomys; it therefore extends from the first occurrence of Microtus (represented by Allophaiomys, which includes primitive members of the genus Microtus) to the disappearance of Mimomys (represented by M. savini) (Fejfar et al. 1998). Allophaiomys and M. savini appear roughly at the same time in Eurasia, around $2 \mathrm{Ma}$.

In Europe, and more specifically in Italy, M. savini characterises both the early Biharian (defined by the cooccurrence of $M$. savini and M. pusillus and correlated with the Calabrian Age, early Early Pleistocene) and the late Biharian (time interval when $M$. savini was not associated with $M$. pusillus), which corresponds approximately to the first part of the early Middle Pleistocene. Readers are kindly referred to Gliozzi et al. (1997), Sala and Masini (2007) and Masini and Sala (2007) for correlations between Fejfar et al.'s (1998) standard biochronological scale based on small mammals and Azzaroli's (1977) Italian Mammal Ages, on the one hand, and the International Chronostratigraphic Scale, on the other.

Mimomys savini is first recorded in Italy based on a few remains from the localities Le Strette and Bosco Chiesa Nuova, in Upper Valdarno, where also large mammal remains of the Tasso Faunal Unit were found (Bosco 1898, 1899, Torre 1985, Sala and Masini 2007). These Lower Pleistocene deposits are magnetostratigraphically correlated with the base of the Calabrian Stage and biochronologically with the early part of the early Biharian; they therefore date to around 1.6-1.8 Ma (Torre et al. 1996, Azzaroli 1998, Masini and Sala 2007, Sala and Masini 2007, Rook and Martínez-Navarro 2010). Breda and Marchetti (2007) correlated the $M$. cf. savini bearing levels of Leffe (Stehlin 1930, Masini et al. 1996) with the transition between the Early Pleistocene Tasso and Farneta Faunal units and therefore with the early Biharian. Scoppito (L'Aquila Basin) is yet another early Biharian site that yielded Mimomys savini (Masini et al. 1996, Kotsakis et al. 2003). A younger age is assumed for the fossiliferous site of Soave/ Cava Sud (Mimomys cf. savini) (Pasa 1947, Bartolomei 1980, Masini and Santini 1991), and further Italian early Biharian sites with M. savini are Monte Peglia (Van der Meulen 1973, Masini et al. 1998), and Castagnone/Pontrestura I (Northern Monferrato, Piedmont, NW Italy) (Siori and Sala 2007). In the latter site fossils come from both the basal levels of the local sedimentary succession ( $1^{\text {st }}$ Alluvial Unit, fluviatile deposits and soils) and from the Alluvial Unit, at the (pedogenetic) top of the sequence. At least the basal levels are late Early Pleistocene (late early Biharian) in age because $M$. savini co-occurs with evolved representatives of Microtus (Allophaiomys) cf. nutiensis, Mimomys pusillus, and Ungaromys cf. nanus (Giraudi et al. 2003, Sala and Masini 2007, Siori and Sala 2007). The fossil bearing stratigraphical sequence yielded a positive magnetization referred to the Jaramillo by Giraudi et al. (2003).

Late Biharian faunas with M. savini were found at Soave/ Monte Tenda (Bon et al. 1991, Masini et al. 1996), and Slivia (Ambrosetti et al. 1979, Bon et al. 1991, Gliozzi et al. 1997). Scant, late Biharian remains of $M$. savini, somewhat more recent than the specimens from Soave/Monte Tenda, also come from Rifreddo in Sant'Arcangelo Basin (Basilicata), which yielded Microtus (Terricola) arvalidens, Microtus (Iberomys) ex gr. huescarensis-brecciensis, Macroneomys cf. brachygnathus and which show normal magnetisation of the early part of the Brunhes magnetochron (Fanfani 2000, Masini et al. 2000, 2005).

\section{Arvicola mosbachensis}

The oldest Italian Arvicola is from Isernia La Pineta. Although its age and taxonomic position have been debated (e.g., Koenigswald and Van Kolfschoten 1996, Maul et al. 2000 ) it is a very primitive $A$. mosbachensis still with incipient roots in some upper molars (see also Sala and Masini 2007). The fossil-bearing layers are ${ }^{40} \mathrm{Ar} /{ }^{39} \mathrm{Ar}$ dated to about $600 \mathrm{ka}$ (Coltorti et al. 2005). A. mosbachensis is not very abundant in Middle Pleistocene localities, but its stratigraphic distribution is fairly continuous. The most significant localities where it was found are Venosa Notarchirico (Basilicata) (Sala 1999) and Visogliano Shelter (inner and outer deposits) (Cattani et al. 1991, Abbazzi et al. 2000). It was also found in recently discovered localities, such as Campani Quarry (Marcolini et al. 2000, 2003, Marcolini 2002), Cretone (Latium) (Di Canzio et al. 2003) and Campitello Quarry (Upper Valdarno, Tuscany) (Mazza et al. 2006) where an "evolved form" is quoted. A. cf. mosbachensis is reported from Fontana Marella Cave (Lombardian pre-Alps Varese Northern Italy); its remains were found in a layer sealed by a flowstone dated to $350 \mathrm{ka}$ (Bona et al. 2008). Cretone is referred to the "Torre in Pietra" Faunal Unit of the Italian biochronological scale (Gliozzi et al. 1997) and correlated with MIS 10-9 (Milli and Palombo 2005). A number of finds, referred to as $A$. mosbachensis and Arvicola sp., and considered early Toringian in age, come from karst deposits in Verona and Friuli-Venezia Giulia (a more detailed report on these finds see in Pasa 1947, Bon et al. 1991, Kotsakis et al. 2003). Unfortunately, almost all the finds of this species have received scarce attention so far, and morphometric and morphologic descriptions are lacking.

\section{Arvicola amphibius group}

Arvicola amphibius (resp. cited as A. terrestris) is reported from the majority of Last Glacial Italian sites (Kotsakis et al. 2003). Its first occurrence apparently precedes the Last Interglacial. A. amphibius and Arvicola sp. were found in several pre-Eemian localities of Italy (Kotsakis et al. 2003, Sala and Masini 2007). Fossil finds of A. amphibius are reported from all over the peninsula, with the exception of southern Apulia. A. amphibius is absent from Sardinia and is reported only from the early-mid Holocene in Sicily (Tagliacozzo 1993, Catalisano and Sarà 1995, Agnesi et al. 
2000, López-García et al. 2013). The latter authors gave a ${ }^{14} \mathrm{C}$ dating of 3,950 \pm 35 years to the youngest occurrence of Arvicola at Vallone Inferno, Northern Sicily. The morphology of A. amphibius is imperfectly known like that of Arvicola mosbachensis, since only a very few samples are properly figured and described (Maul et al. 1998b), whereas almost all the other occurrences are simple quotations in faunal lists. The recently published finds of water vole from Cava Muracci in Latium (dated at MIS 3) are referred to A. italicus by Gatta et al. (1998) who, however, do not report information on SDQ of these specimens.

\section{Extant Arvicola in Italy}

Over the last thirty years Arvicola amphibius (= terrestris) was commonly thought to be Italy's only water vole. In his careful report on the Italian fauna, Toschi (1965) considered two valid subspecies: A terrestris italicus, allegedly distributed in northern and central Italy, but also present in southern Switzerland as well as in the north-west of the Balkan Peninsula, and $A$. terrestris musignani, from central to southern Italy. The distributions of two subspecies were thought to partially overlap. According to Toschi (1965) the two subspecies were adapted to both fossorial and aquatic ways of life, similarly to the Alpine representatives and A. sapidus, respectively. Toschi (1965) reported the possible occurrence of a "more aquatic" population, geographically isolated on the Sila Mountains (Calabria). Eventually, Lapini and Paolucci (1994) suggest that in north-eastern Italy there are two subspecies, one, the fossorial $A$. terrestris scherman, distributed in mountainous areas (Carnic Alps) and the other, A. terrestris italicus, typical of the valley bottoms and of low altitude flatlands.

According to Castiglia et al. (2016), the current taxonomy includes two endemic taxa (Gippoliti 2012) considered as subspecies (Cagnin 2008): A. amphibius italicus SAVI, 1839, restricted to central-northern Italy, and A. amphibius musignani DE Sélys LongChamps, 1839, thought to be distributed in central-southern Italy.

Castiglia et al. (2016) revised Wust-Saucy's (1998) and Taberlet's (1998) studies and claimed significant differences discriminating the two "Italian clades, one with north western distribution and the other with central southern distribution", from the "western European clade" and a large group indicated as "Euro-Asiatic clade". They proposed to use the name $A$. italicus for the Italian water voles and ignored $A$. scherman (Castiglia et al. 2016).

Wust-Saucy's (1998) and Taberlet's (1998) molecularbased phylogeny and dispersals changed significantly the taxonomy of European and Italian water voles. The taxonomic-phylogenetic revision revealed a more complex evolution of Arvicola than previously assumed, and yet many taxonomic aspects still remain unclear.

\section{Quantitative comparisons of $\mathrm{m} 1$ from Italy and selected areas of Europe}

\section{Material and methods}

\section{Material}

Two samples of Mimomys savini and 58 both fossil and extant samples of various Arvicola populations are considered in the analysis (Tab. 1). Several samples have been measured directly, while data from the literature have been used for others (Tab. 1, Text-fig. 4). The list of the locations and short descriptions of the examined sites are to be found in Appendix A.

\section{Compared parameters}

Three parameters of the lower first molar $\mathrm{m} 1$ have been used (Text-fig. 3): (1) the total length L, (2) the relative length of the Anteroconid complex (ACC), index A/L $(=$ Anteroconid length A / total length L] $\times 100)$ ratio, introduced by Van der Meulen (1973) for Microtus molars, (3) the SDQ (Enamel Differentiation Quotient = ratio of thickness of the posterior to the anterior enamel edges of all salient angles in $\mathrm{m} 1$ ) ratio, introduced by Heinrich (1978).

Comparisons based on indexes $\mathrm{B} / \mathrm{W}$ and $\mathrm{C} / \mathrm{W}$ of the occlusal surface (cf. Van der Meulen 1973) did not show significant patterns, and are thus not included in this report. $\mathrm{L}$ and $\mathrm{A} / \mathrm{L}$ display evolutionary trends towards increasing values (Fejfar 1972, Van der Meulen 1973), whereas the opposite is observed with SDQ (Heinrich 1978). A list of basic statistics of each measurement or index for almost each locality, is given in Appendix B.

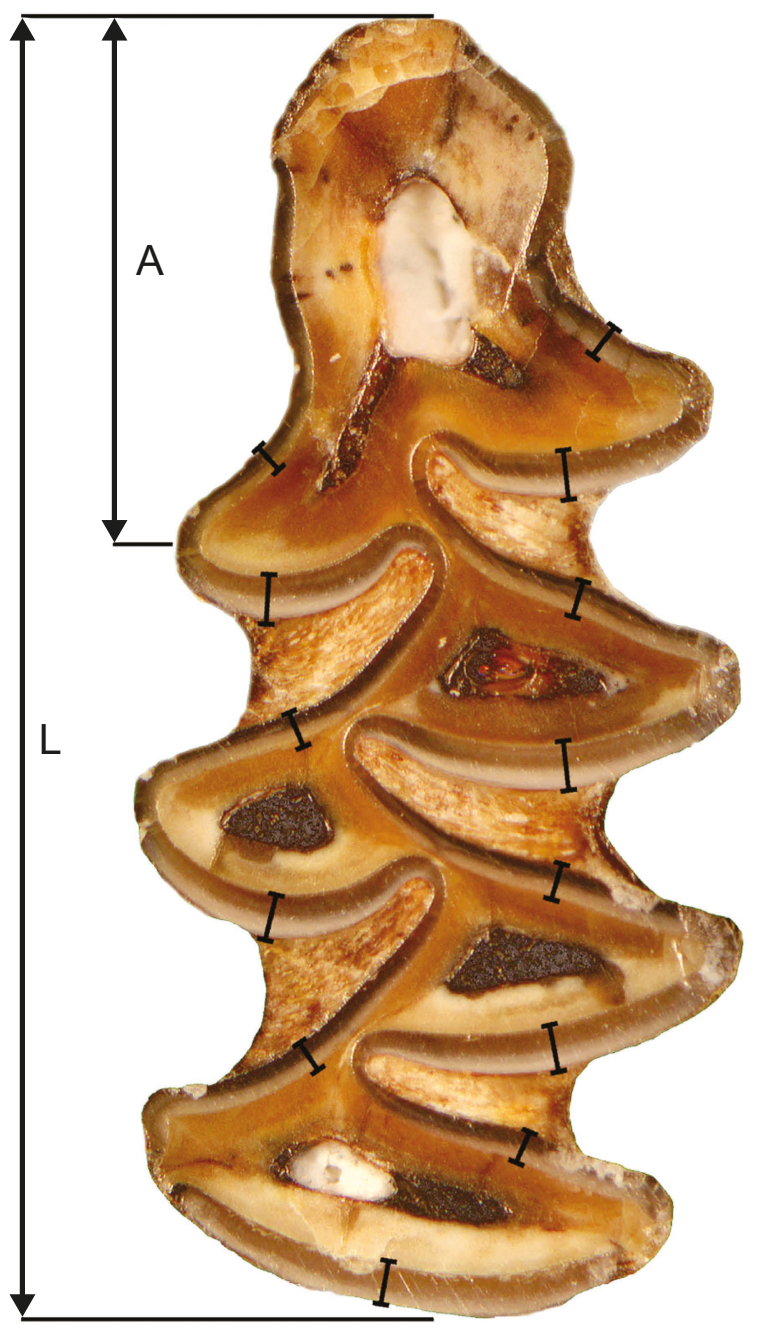

Text-fig. 3. Scheme of measurement of the first molar of Mimomys and Arvicola adopted in the present work. L - maximal length, A - anteroconid length. 
Table 1. Compilation of $\mathrm{L}, \mathrm{A} / \mathrm{L}$, and SDQ values for all examined samples. Reported values are those used in the plots. Symbols are used the same as in Text-fig. 4.

\begin{tabular}{|c|c|c|c|c|c|c|c|c|c|c|}
\hline Taxon & $\begin{array}{l}\text { Geographic } \\
\text { Location }\end{array}$ & $\begin{array}{c}\text { Locality / Site } \\
\text { Stratigraphic horizon }\end{array}$ & $\mathbf{L}$ & SDQ & $\mathbf{A} / \mathbf{L}$ & $\mathbf{n}$ & Age & $\begin{array}{l}\text { Time } \\
\text { slice }\end{array}$ & Source & Symbol \\
\hline A. sapidus & Spain & Madrid & 4.35 & 122.96 & 40.80 & 16 & $\operatorname{Rec}$ & 1 & This paper & O \\
\hline A. amphibius & Austria & Graz. Rabwitz & 3.86 & 99.28 & 42.07 & 10 & $\operatorname{Rec}$ & 1 & This paper & \\
\hline A. amphibius & Germany & Eisfeld & 3.79 & 84.91 & & 30 & $\operatorname{Rec}$ & 1 & Frahnert 1991 & \\
\hline A. amphibius & Germany & Langen & 3.69 & 89.96 & 43.42 & 7 & $\operatorname{Rec}$ & 1 & Maul et al. 1998 & \\
\hline A. amphibius & Italy North & Delta Po & 3.85 & 112.97 & 43.58 & 17 & $\operatorname{Rec}$ & 1 & This paper & 0 \\
\hline A. amphibius & Italy North & Rovigo & 3.83 & 116.47 & 43.76 & 6 & $\operatorname{Rec}$ & 1 & This paper & \\
\hline A. amphibius & Italy North & Ferrara & 4.03 & 114.67 & 44.97 & 7 & $\operatorname{Rec}$ & 1 & This paper & \\
\hline A. amphibius & Italy South & Calabria & 3.98 & 103.85 & 44.58 & 12 & $\operatorname{Rec}$ & 1 & This paper & \\
\hline A. amphibius & Italy N. East & Caverna degli Orsi-Holocene & 3.82 & 107.22 & 41.98 & 8 & MIS 1 & 2 & This paper & \\
\hline A. ex gr. amphibius & Italy $\mathrm{N}$. West & Arma delle Manie 7-3 & 4.00 & 99.84 & & 25 & MIS 4 & 3 & Desclaux et al. 2000 & \\
\hline A. ex gr. amphibius & Italy N. West & Riparo Mochi 1 & 4.06 & 100.75 & & 11 & MIS 3 & 3 & Desclaux et al. 2000 & \\
\hline A. ex gr. amphibius & Italy N. West & Riparo Mochi 2 & 3.96 & 98.20 & & 29 & MIS 3 & 3 & Desclaux et al. 2000 & \\
\hline A. ex gr. amphibius & Italy South & Grotta di Castelcivita & 4.02 & 108.12 & 43.10 & 26 & MIS 3 & 3 & Maul et al. 1998 & \\
\hline A. ex gr. amphibius & Italy South & Grotta della Serratura & 4.11 & 113.58 & 42.60 & 28 & MIS 2 & 3 & This paper & \\
\hline A. ex gr. amphibius & Italy South & Grotta del Romito & 4.05 & 110.06 & 43.10 & 19 & MIS 2 & 3 & This paper & \\
\hline A. ex gr. amphibius & Italy South & Scario Grotta Grande - sector A & 4.08 & 116.61 & 42.64 & 5 & MIS 5 & 4 & Maul et al. 1998 & \\
\hline A. ex gr. amphibius & Italy Central & Grotta di Cucigliana & 4.14 & 110.99 & 41.11 & 4 & MIS 5 & 4 & This paper & \\
\hline A. ex gr. amphibius & Italy South & Scario Grotta Grande - sector SG & 4.07 & 121.39 & 43.44 & 3 & MIS 6 & 5 & Maul et al. 1998 & \\
\hline A. ex gr. amphibius & Ialy Central & Upper Valdarno Campitello & 3.95 & 114.17 & 42.00 & 2 & MIS $6 ?$ & 5 & This paper & \\
\hline A. mosbachensis & Italy N. East & Riparo di Visogliano ext. breccia & 3.39 & 123.42 & 39.14 & 13 & M-Pleist & 6 & This paper & \\
\hline A. mosbachensis & Italy N. East & Riparo di Visogliano A L. levels & 3.47 & 122.77 & 39.19 & 2 & M-Pleist & 6 & This paper & \\
\hline A. mosbachensis & Italy N. East & Riparo di Visogliano A U. level 2 & 3.43 & 122.89 & 40.30 & 18 & M-Pleist & 6 & This paper & \\
\hline A. mosbachensis & Italy N. East & Riparo di Visogliano A U. level 1 & 3.38 & 116.43 & 38.51 & 17 & M-Pleist & 6 & This paper & \\
\hline A. mosbachensis & Italy South & Isernia la Pineta & 3.48 & 134.08 & 40.66 & 8 & M-Pleist & 6 & Maul et al. 1998 & \\
\hline A. ex gr. amphibius & France East & Baume Gigny 6 & 4.07 & 78.40 & & 30 & MIS 2 & 3 & Desclaux et al. 2000 & \\
\hline A. ex gr. amphibius & France East & Baume Gigny 10 & 3.89 & 87.50 & & 34 & MIS 3 & 3 & Desclaux et al. 2000 & \\
\hline A. ex gr. amphibius & France S. East & Baume Moula Guercy 8-4 & 3.90 & 81.00 & & 5 & MIS 4 & 3 & Desclaux et al. 2000 & \\
\hline A. ex gr. amphibius & France S. West & Grotte de 1'Eglise II & 4.02 & 83.59 & & 31 & MIS 4 ? & 3 & Desclaux et al. 2000 & \\
\hline A. ex gr. amphibius & France S. West & Grotte-abri Suard & 4.00 & 91.59 & & 32 & Würmian-early & 3 & Desclaux et al. 2000 & \\
\hline A. ex gr. amphibius & France East & Baume Gigny-19a & 3.76 & 96.40 & & 18 & MIS 5a & 4 & Desclaux et al. 2000 & \\
\hline A. ex gr. amphibius & France S. West & Grotte d'Artenac-c10 & 3.73 & 99.96 & & 21 & MIS 5 & 4 & Desclaux et al. 2000 & \\
\hline A. ex gr. amphibius & France S. West & Grotte d'Artenac-c8 & 3.73 & 93.85 & & 14 & MIS 5d-a & 4 & Desclaux et al. 2000 & $\triangle$ \\
\hline A. ex gr. amphibius & France East & Baume Gigny 20-19c & 3.74 & 93.68 & & 41 & MIS 5d-c & 4 & Desclaux et al. 2000 & \\
\hline A. ex gr. amphibius & France S. East & Pié Lombard & 3.71 & 101.02 & & 4 & MIS 5d-c & 4 & Desclaux et al. 2000 & \\
\hline A. ex gr. amphibius & France S. East & Baume Moula Guercy $15-14$ & 3.83 & 100.53 & & 15 & MIS 5e & 4 & Desclaux et al. 2000 & \\
\hline A. ex gr. amphibius & France S. West & Abri Vaufrey-8 & 3.87 & 94.19 & & 31 & Riss-late & 5 & Desclaux et al. 2000 & \\
\hline A. ex gr. amphibius & France S. East & Baume Moula Guercy 19-18 & 3.82 & 87.41 & & 31 & Riss-late & 5 & Desclaux et al. 2000 & \\
\hline A. ex gr. amphibius & France East & Baume Gigny 22-19 & 4.21 & 94.00 & & 65 & Riss & 5 & Desclaux et al. 2000 & \\
\hline A. ex gr. amphibius & France S. East & Grotte du Lazaret & 3.85 & 107.90 & & 47 & Riss & 5 & Desclaux et al. 2000 & \\
\hline Arvicola sp. & France S. West & Abri Gaudry & 3.89 & 113.90 & & 64 & MIS $8 ?$ & 5 & Desclaux et al. 2000 & \\
\hline A. amphibius & Germany & Pisede & 4.05 & 80.17 & & 144 & Holocene & 2 & $\begin{array}{l}\text { Heinrich and Maul } \\
1983\end{array}$ & \\
\hline A. ex gr. amphibius & Germany & Euerwanger Bühl & 4.09 & 83.03 & & 27 & Weichselian & 3 & Heinrich 1982 & \\
\hline A. ex gr. amphibius & Germany & Kemathenhöhle & 4.05 & 89.23 & & 11 & Weichselian & 3 & Heinrich 1982 & \\
\hline A. ex gr. amphibius & Germany & Krockstein (Rübeland 1) & 4.04 & 89.08 & & 40 & Weichselian & 3 & Heinrich 1982 & \\
\hline A. ex gr. amphibius & Germany & Burgtonna 2 & 3.76 & 99.65 & & 41 & Würmian-early & 3 & Heinrich 1982 & \\
\hline A. ex gr. amphibius & Germany & Burgtonna $\mathrm{Cm}$ & 3.82 & 78.91 & & 11 & Eemian & 4 & This paper & \\
\hline A. ex gr. amphibius & Germany & Burgtonna Hy & 3.88 & 103.66 & 41.64 & 10 & Eemian & 4 & This paper & \\
\hline A. ex gr. amphibius & Germany & Parkhöhle (Weimar) & 3.90 & 109.62 & & 3 & Eemian & 4 & Heinrich 1982 & $\triangle$ \\
\hline A. ex gr. amphibius & Germany & Stuttgart-Untertürkheim & 3.81 & 101.19 & & 37 & Eemian & 4 & Heinrich 1987 & \\
\hline A. ex gr. amphibius & Germany & Taubach & 3.95 & 105.15 & & 11 & Eemian & 4 & Heinrich 1982 & \\
\hline A. ex gr. amphibius & Germany & Ehringsdorf & 3.70 & 112.30 & & 8 & Saalian-early & 5 & Heinrich 1982 & \\
\hline A. ex gr. amphibius & Germany & Plaidter-Hummerich & 3.80 & 82.17 & & 5 & Saalian & 5 & $\begin{array}{l}\text { Van Kolfschoten } \\
1990\end{array}$ & \\
\hline A. mosbachensis & Germany & Mosbach 2 & 3.23 & 133.34 & 39.93 & 44 & M-Pleist & 6 & Maul et al. 2000 & \\
\hline A. mosbachensis & Germany & Petersbuch 1 & 3.65 & 126.16 & & 10 & M-Pleist & 6 & Maul et al. 2000 & \\
\hline A. mosbachensis & Germany & Bilzingsleben 2 & 3.58 & 132.10 & & 9 & M-Pleist & 6 & Maul et al. 2000 & \\
\hline A. mosbachensis & Germany & Miesenheim 1 & 3.48 & 140.62 & & 9 & M-Pleist & 6 & Maul et al. 2000 & \\
\hline M. savini & Germany & Voigtstedt & 3.53 & 139.09 & & 108 & M-Pleist & 7 & Maul et al. 2014 & \\
\hline M. savini & Germany & Untermassfeld & 3.14 & 153.20 & & 9 & E-Pleist & 8 & Maul 2001 & \\
\hline
\end{tabular}




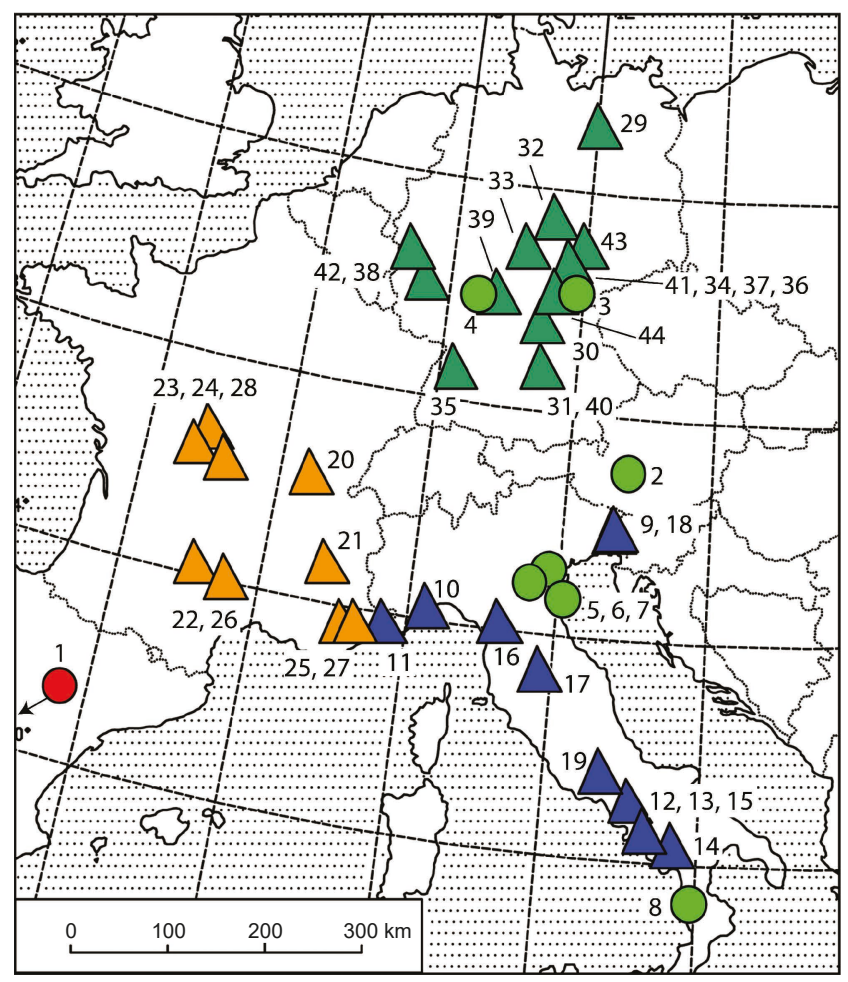

Text-fig. 4. Location Map of the examined water vole localities. From Masini et al. (2007), modified. 1: Madrid, surroundings, 2: Graz, 3: Eisfeld, 4: Langen, 5: Delta Po, 6: Rovigo, 7: Ferrara, 8: Calabria, 9: Caverna degli Orsi, 10: Arma delle Manie, 11: Riparo Mochi, 12: Grotta di Castelcivita, 13: Grotta della Serratura, 14: Grotta del Romito, 15: Scario Grotta Grande, 16: Grotta di Cucigliana, 17: Upper Valdarno Campitello, 18: Riparo di Visogliano, 19: Isernia La Pineta, 20: Baume Gigny, 21: Baume Moula Guercy, 22: Grotte de L'Eglise, 23: Grotte-Abri Suard, 24: Grotte d'Artenac, 25: Pié Lombard, 26: Abri Vaufrey, 27: Grotte du Lazaret, 28: Abri Gaudry, 29: Pisede, 30: Euerwanger Bühl, 31: Kemathenhöhle, 32: Krockstein (Rübeland 1), 33: Burgtonna, 34: Parkhöhle (Weimar), 35: StuttgartUntertürkheim, 36: Taubach, 37: Ehringsdorf, 38: Plaidter-Hummerich, 39: Mosbach, 40: Petersbuch 1, 41: Bilzingsleben, 42: Miesenheim 1, 43: Voigtstedt, 44: Untermassfeld. See Table 1 for symbol explanations.

\section{Chronological frame}

The sites under consideration are dated in different ways (either radiometrically, or climate-stratigraphically and/or biochronologically), and are thus not "homogeneous". For this reason, they have been grouped in eight "time slices" (see Tab. 1). The number and duration of these time slices has been chosen in a way to maximise the number of localities within given time slices and to obtain reasonably reliable stratigraphic resolution. The time slices are the following:

(1) Recent

(2) Holocene (absolute age: 10 to $0 \mathrm{ka}$ )

(3) Würmian/Weichselian (pro parte): MIS 4-2 including the Late Glacial (absolute age: ca. 75 to $10 \mathrm{ka}$ )

(4) Eemian + early Würmian/Weichselian: penultimate interglacial and the following climatic oscillations that precede the onset of first cold phase (MIS 4) of the last glaciation: MIS 5e (Eemian), MIS 5d, b (cold oscillations) and $5 \mathrm{c}$, a (warm oscillations) (absolute age: ca. 125-75 ka)
(5) Pre-Eemian: Rissian/Saalian Glaciation; MIS 6, MIS 7 (absolute age: ca. 250 to $125 \mathrm{ka}$ ), Middle Pleistocene

(6) Time of occurrence of older Arvicola samples (absolute age: ca. 600 to $250 \mathrm{ka}$ )

(7) Time of occurrence of younger Mimomys savini faunas (absolute age: ca. 800 to $600 \mathrm{ka}$ )

(8) Time of occurrence of older Mimomys savini faunas (absolute age: ca. $1 \mathrm{Ma}$ to $800 \mathrm{ka}$ ).

\section{Biogeographical frame}

\section{Remarks on the biogeographical situation}

The Italian territory is not homogeneous biogeographically. For our purpose, at least two areas should be distinguished.

During the Pleistocene and Holocene north-eastern Italy can be separated biogeographically and climatically from the Tyrrhenian regions; also a north-south clinal variation occurs (Sala 1990, 2003, Sala and Marchetti 2004, 2006, Sala and Masini 2007). Particularly, the faunal composition of the Po Valley, north-eastern regions of Veneto Friuli and down south along the Adriatic side of the peninsula, had (and partly still have) affinities with the Balkan province. During cold-arid, glacial climatic phases, "steppe" taxa, like pikas, hamsters, the voles Microtus gregalis and M. oeconomus spread into this north-eastern part of the country (e.g., Sala 1990, 2003, Sala and Marchetti 2004). For example, a vole that was distributed in both the Balkan province and northeastern Italy, is the Balkan snow vole Dinaromys, a genus today endemic to the Balkans. It was present also in northeast Italy since the Late Pliocene and very widespread at the base of the Alpine Arch at least till the early part of the Late Pleistocene.

A similar situation, albeit less commonly reported, existed between the western, Tyrrhenian side of the peninsula and southern France. One of the most notable examples is that of members of the subgenus Microtus (Iberomys), a vole typical of Spain and southern France, which spread from the north western border throughout Italy during the Middle Pleistocene (López-García et al. 2015).

The history of past and extant specimens of Italian Arvicola should reasonably be expected to be influenced by exchanges between populations from neighbouring bioprovinces, but also to show a tendency to undergo endemic evolution.

To highlight the peculiarities of Italian water vole samples, morphometric comparisons were made with their counterparts distributed in Germany, which is situated north of the Alps, is included in the continental biogeographical zone, and experienced directly the effects of glacial ice sheets that extended both from the north (Scandinavian glaciation) and the south (Alpine glaciation). Other specimens included in the analysis come from south-east France and Spain, which are areas of the Mediterranean zone, and from centraleastern France, which is also part of the continental zone.

\section{Results of the quantitative comparison}

\section{Length, $A / L$ and $S D Q$ versus time slices}

The chronological distribution of $\mathrm{L}, \mathrm{A} / \mathrm{L}$, and SDQ values reveals the evolutionary patterns and rates of morphologic change of the vole teeth considered in this 


\section{AL vs Time Slices}

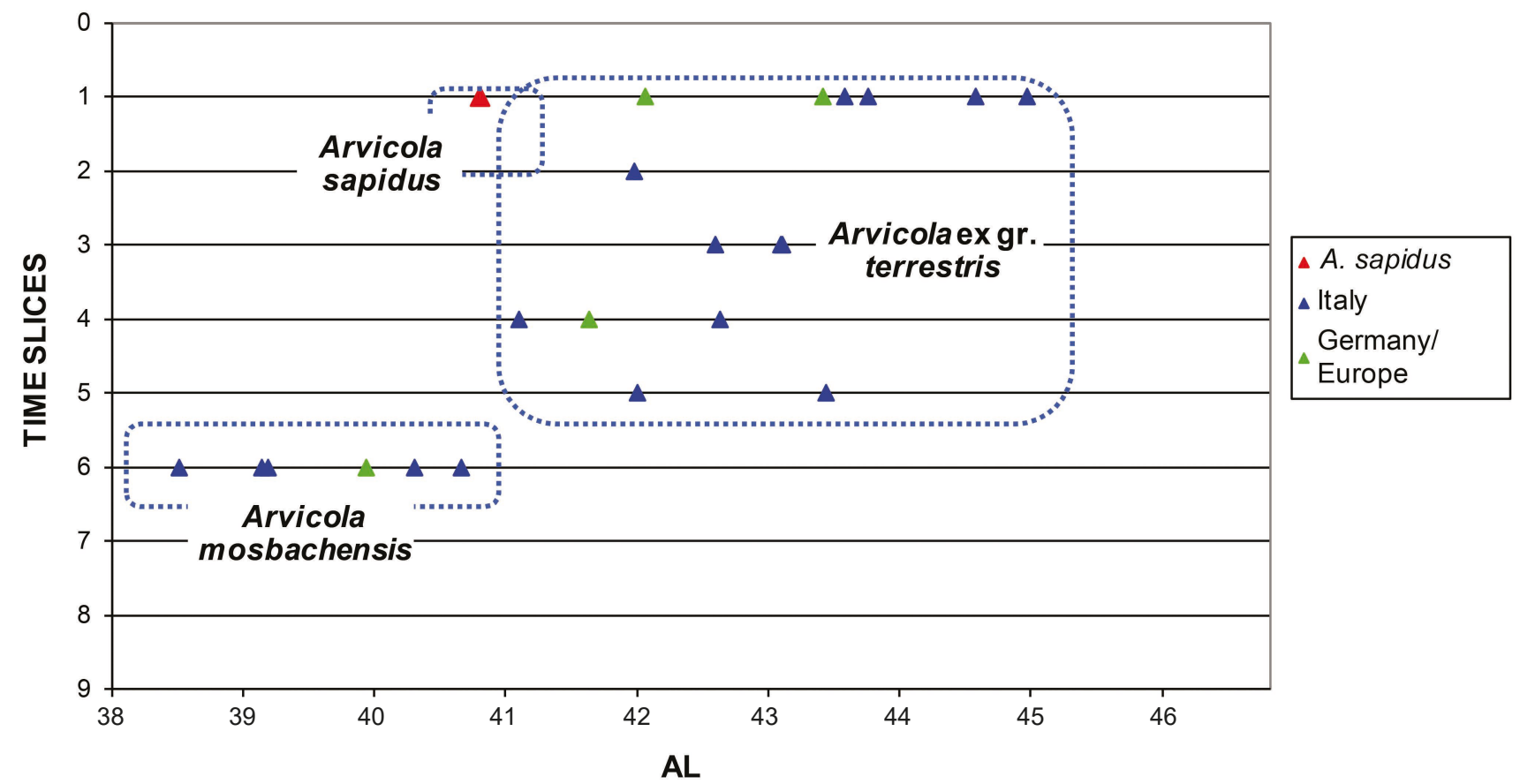

Text-fig. 5. Diagram showing the variation of Anteroconid length (index A/L) vs Time slices in m1s of $M$. savini and Arvicola from different geographical provenances.

study (Text-figs 5-7). These values exhibit a certain degree of correlation and strong directional and correlated increment from the most primitive taxon (Mimomys savini) to the primitive Arvicola (A. mosbachensis) and then to the fossil and recent samples of the $A$. amphibius group (which likely includes also representatives of $A$. italicus). However, age and geographical differences are visible.
M. savini displays the smallest values of $\mathrm{L}$ and the greatest of SDQ, with minimum overlap with $A$. mosbachensis. A. mosbachensis and the A. amphibius group are clearly separated in the development of the anteroconid complex (A/L), whereas there is an overlap in SDQ between A. mosbachensis and the minimum values of $A$. amphibius. The size of $A$. mosbachensis is relatively small and overlaps

\section{SDQ vs Tíme Slices}

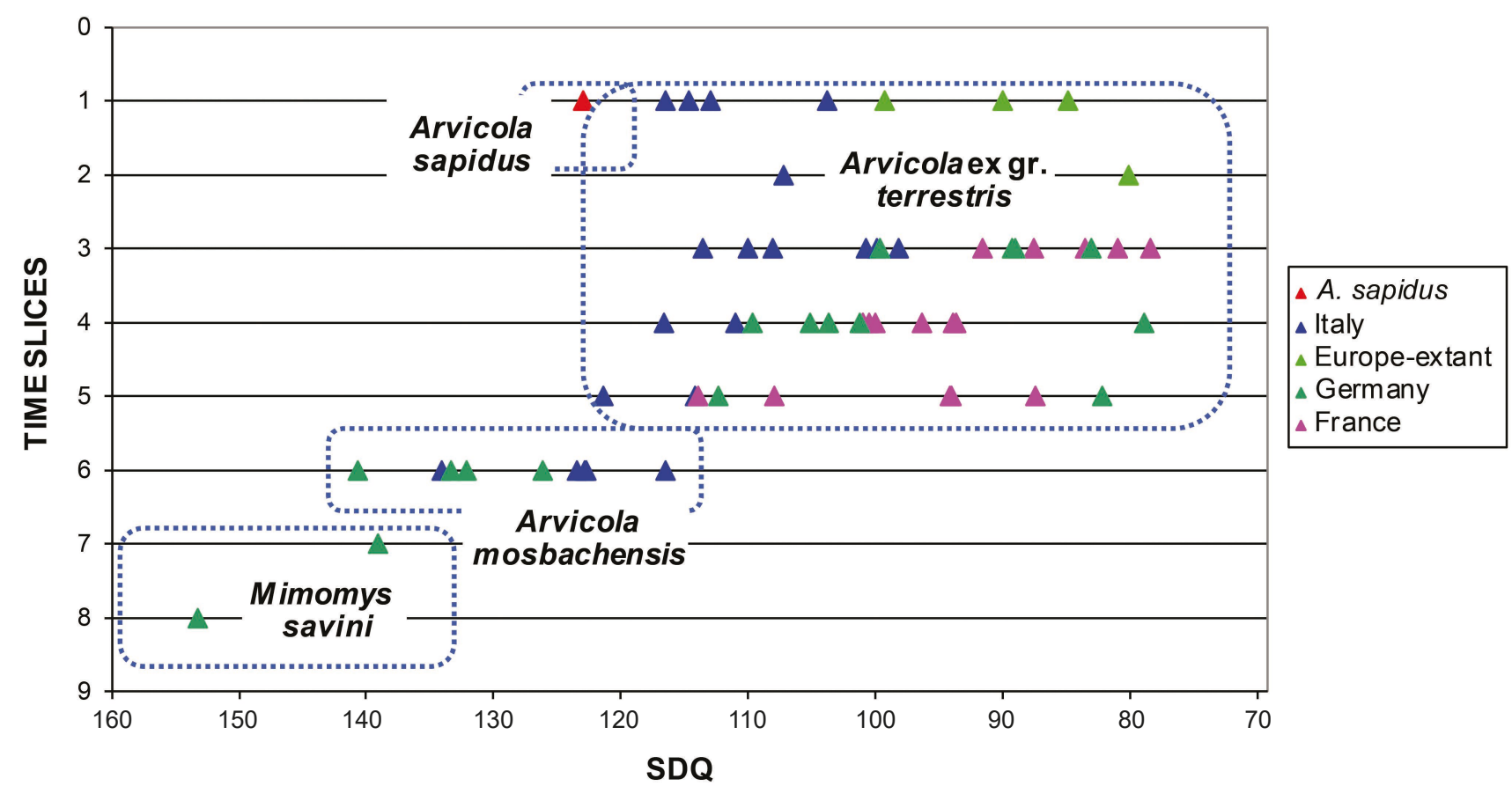

Text-fig. 6. Diagram showing the variation of the enamel pattern (index SDQ) vs Time slices in m1s of $M$. savini and Arvicola from different geographical provenances. 


\section{Length vs Time Slices}

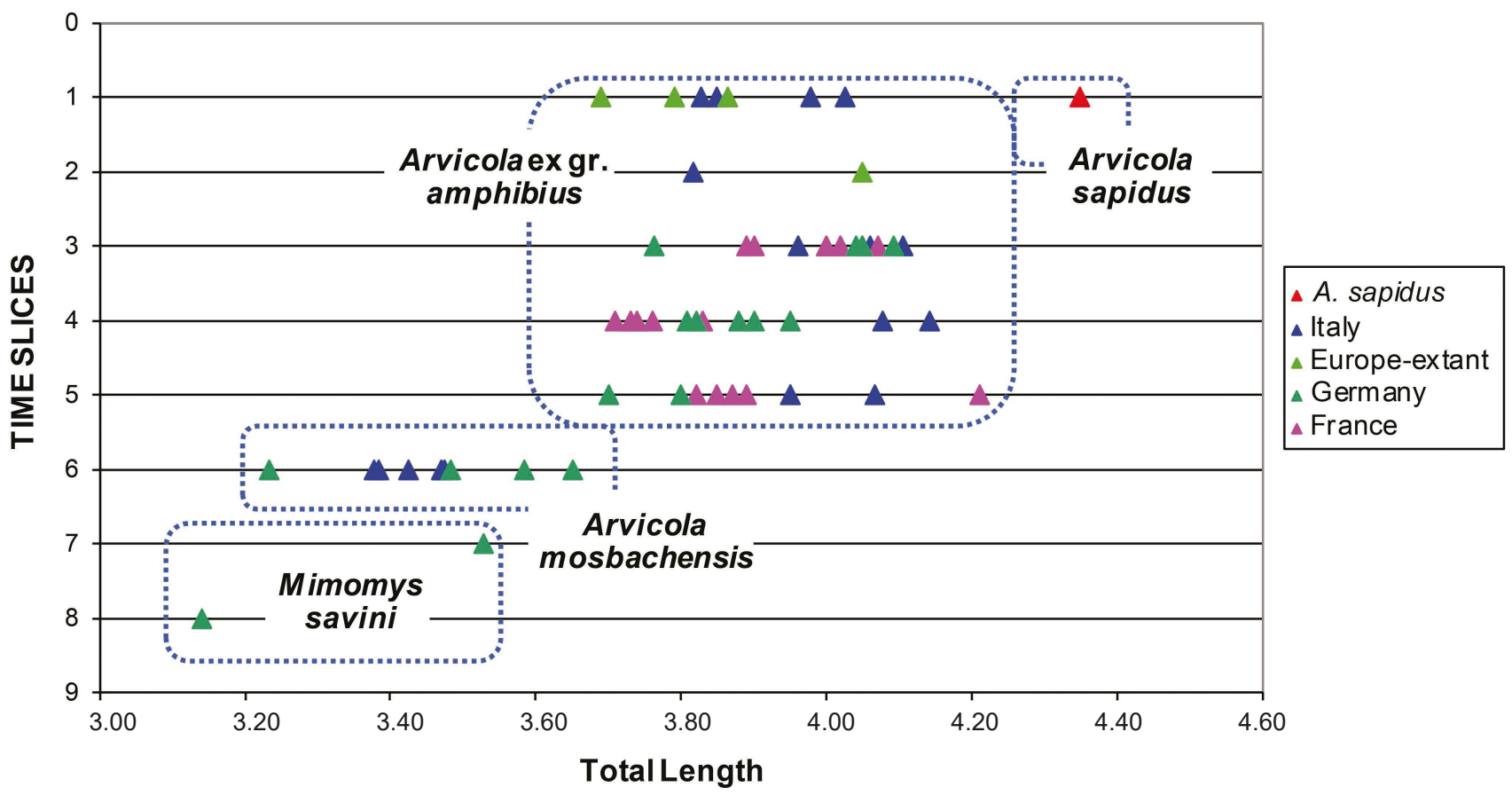

Text-fig. 7. Diagram showing the variation of the size (L) vs Time slices in m1s of $M$. savini and Arvicola from different geographical provenances.

with the medium- and large-sized specimens of M. savini samples. Notable is that the $\mathrm{A} / \mathrm{L}$ values of the Spanish A. sapidus are very close to the minimum values of the A. amphibius group; A. sapidus also has large SDQ values, although exhibiting the largest size.

\section{A/L vs $S D Q$ (0.6 Ma to Recent)}

The A/L vs SDQ diagram (Text-fig. 8) confirms the clear separation between the stratigraphically older Arvicola mosbachensis and the A. amphibius group. The latter are larger sized, have more elongated ACC and lower SDQ values. Therefore, the enamel wall in the teeth of the A. amphibius group tends to be thinner on the posterior edges than anterior ones. Extant A. sapidus maintains SDQ and $\mathrm{A} / \mathrm{L}$ values typical of primitive members compared to the $A$. amphibius group.

The SDQ vs L plot diagram (Text-fig. 9) confirms the separation of $A$. mosbachensis from the A. amphibius group, and shows the clear separation of $A$. sapidus from both species. The A. amphibius group displays rather scattered, overlapping areas.

All the plots show a clear separation between A. Bmosbachensis and the A amphibius group (Text-figs 1013). The former is smaller-sized (mean values of $\mathrm{m} 1$ Length range from 3.23 to $3.65 \mathrm{~mm}$ in Mosbach 2 and Petersbuch 1, respectively), has shorter ACC (mean values for the considered populations range from 38.53 to $40.66 \mathrm{~mm}$ ) and higher (more primitive) SDQ values than the latter (Textfigs 5-7, Tab. 1) (values range from 140.6 in Miesenheim 1, to 116.5 in the Upper Levels of Visogliano A). M. savini from Voigtstedt (an advanced population, close in age to the oldest $A$. mosbachensis) has size and SDQ values that fall in the field of variation of $A$. mosbachensis, which confirms the phyletic relationship between the two taxa.

Another interesting result is that obtained with the recent population of $A$. sapidus. Also, this water vole plots away from $A$. mosbachensis and the A. amphibius group for its much larger size (length of $\mathrm{m} 1$ greater than $4.3 \mathrm{~mm}$ in the considered population), moderately developed ACC (A/L = 40.8) and primitive enamel differentiation (SDQ value of 122.10). It is evident that the species evolved independently both phylogeographically and morphologically.

The Arvicola amphibius group exhibits the greatest degree of variation. This reflects the fact that the group actually includes the majority of the fossil and non-fossil specimens used for this study and also that the non-fossil teeth come from very different geographical areas (Italy, France, Austria, and Germany).

The A/L vs SDQ bivariate plot is based on a limited number of observations. The $\mathrm{A} / \mathrm{L}$ parameter is available only for A. mosbachensis, A. sapidus and for fossil and recent specimens of the $A$. amphibius group from the Italian Peninsula and from a small number of European populations (see also Appendix B).

In Text-fig. 8 past and living populations of the A. amphibius group appear to be characterised by elongated $\mathrm{ACC}$, and by relatively low values of the enamel quotient, in line with the general evolutionary tendency of genus Arvicola outlined above. In this limited subset of data, the Italian specimens, especially the fossil ones from the central southern peninsula, are characterised by a higher enamel quotient (i.e., more primitive enamel pattern) than the recent European populations used for comparison. Recent Italian specimens also show a tendency to have slightly longer ACC. 


\section{All Samples - 0.6 Ma to Recent}

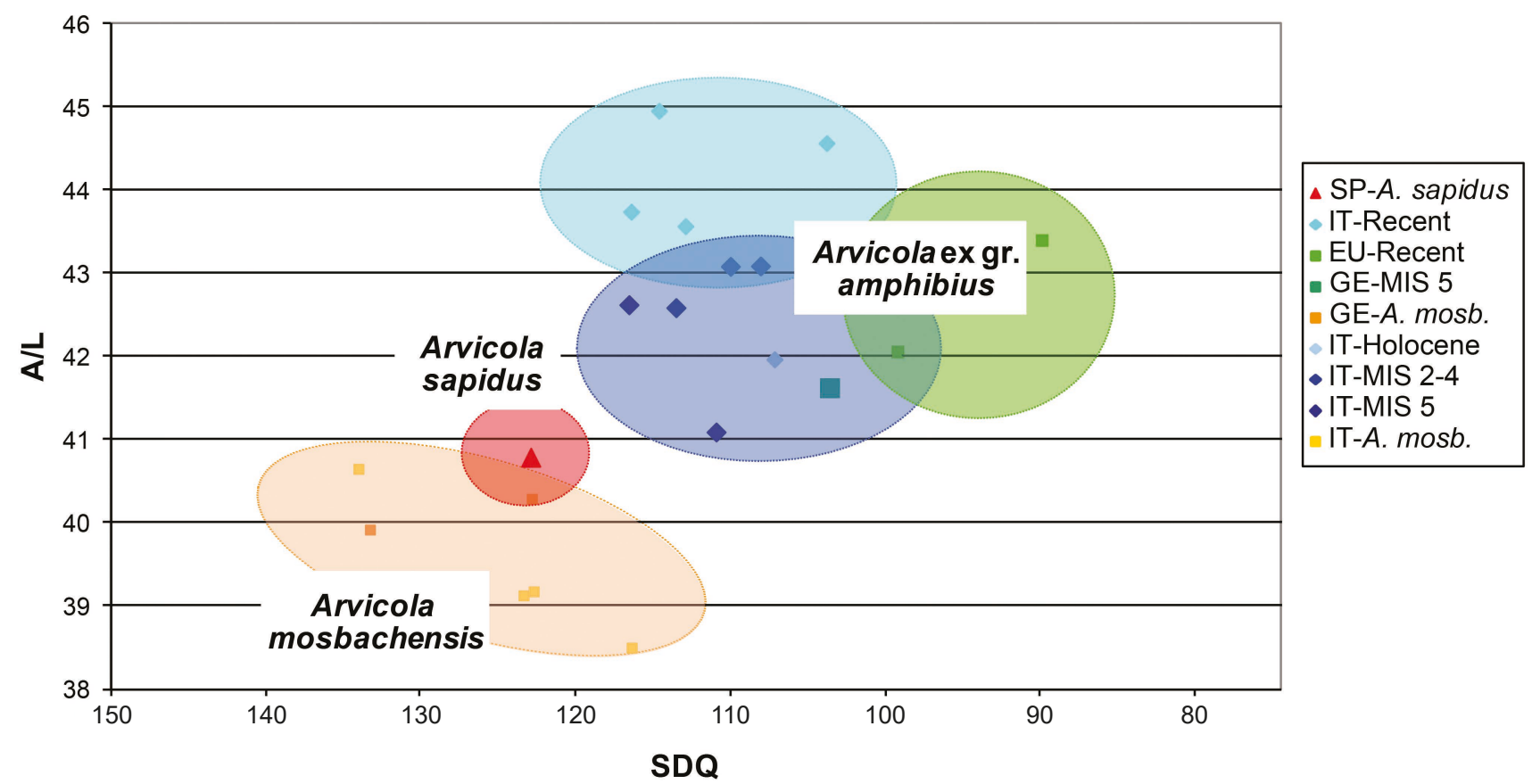

Text-fig. 8. Scatter diagram of SDQ vs A/L M. savini and Arvicola from different geographical provenances and ages.

SDQ vs L (0.6 Ma to Recent)

The diagram of the quotient of enamel thickness versus the length of $\mathrm{m} 1$ is particularly interesting. It includes the greatest number of observations and permits an exhaustive evaluation of the inter-population variation (Text-fig. 9).
The diagram contains a considerable amount of information (both geographical and stratigraphical). It has therefore been analysed step-wise, starting from the recent population and then progressively passing to older specimens (Würmian/Weichselian - Eemian - Rissian/Saalian).

\section{All Samples - 0.6 Ma to Recent}

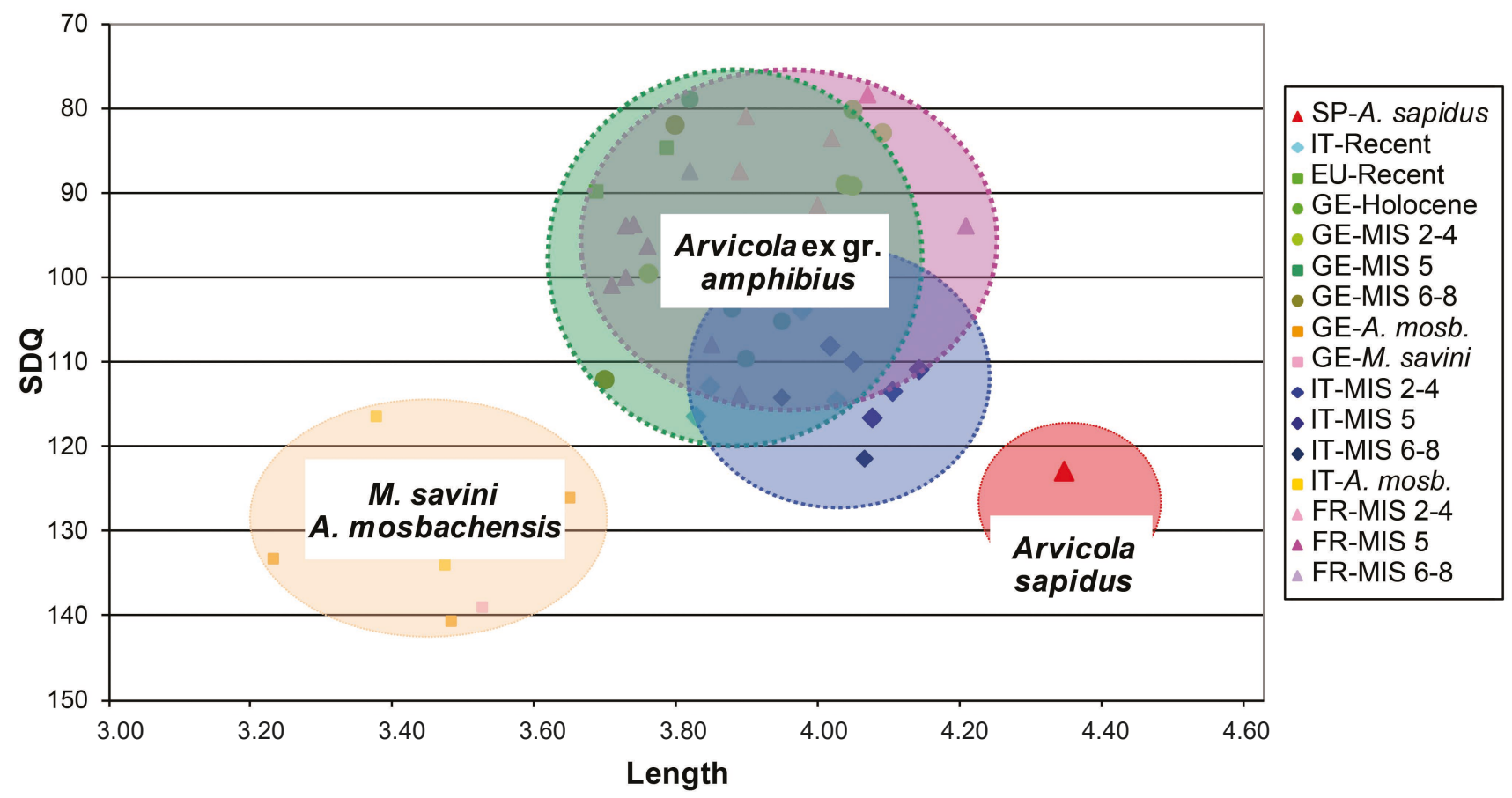

Text-fig. 9. Scatter diagram of $\mathrm{m} 1$ length vs SDQ for $M$. savini and Arvicola from different geographical provenances and ages. 


\section{Recent - Holocene}

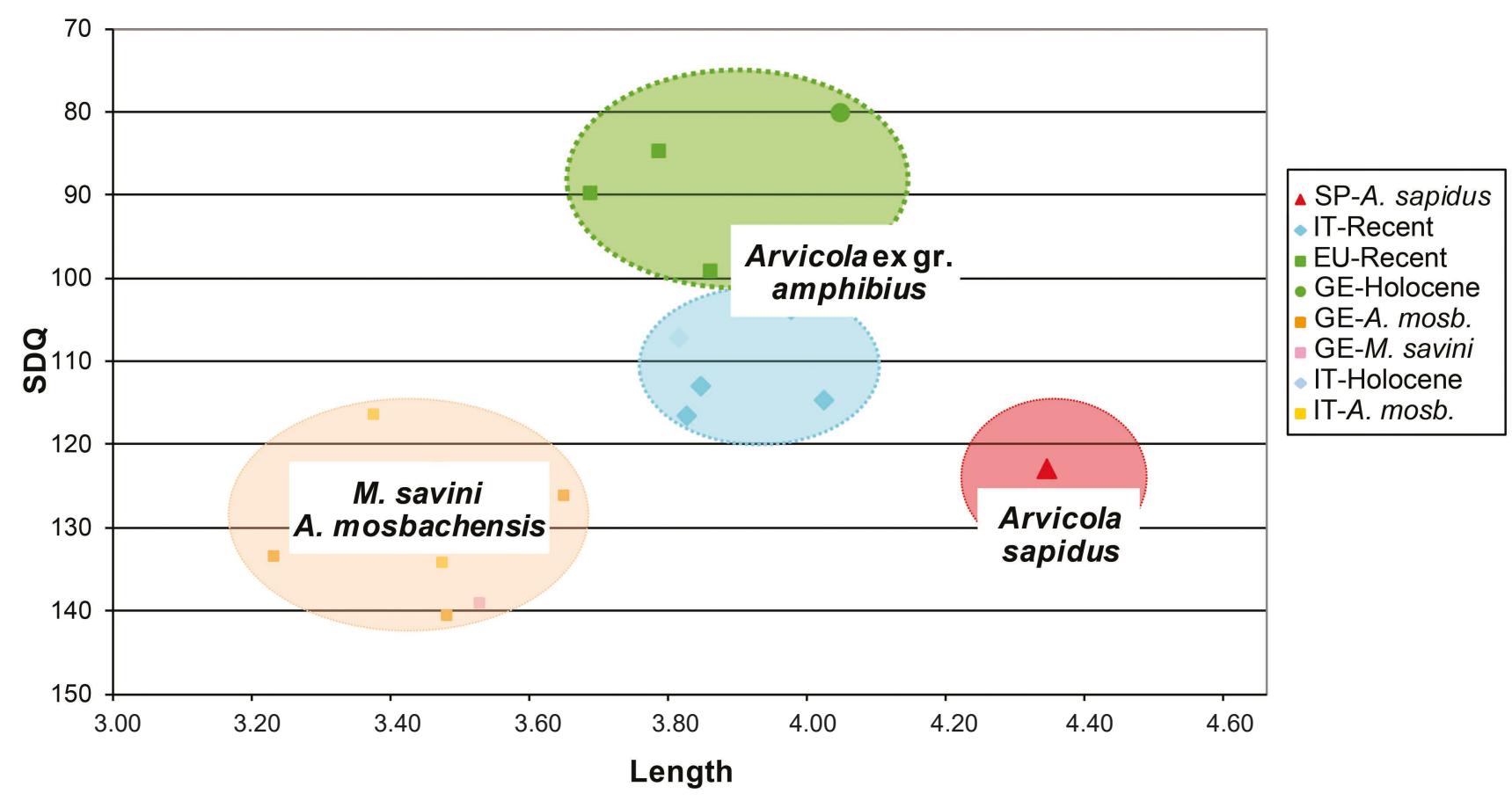

Text-fig. 10. Scatter diagram of $\mathrm{m} 1$ length vs SDQ for Extant (time slice 1 and 2) Arvicola samples of different geographical provenances compared with M. savini-A. mosbachensis. Abbreviations: EU - Europe, GE - Germany, IT - Italy, SP - Spain.

\section{Recent and Holocene specimens}

As already noted, the recent population of Italy forms a "cloud" characterised with slightly higher SDQ values than those of the western and central European group of A. amphibius (Text-fig. 10). Most of the teeth gave negative to undifferentiated values $(120 \geq \mathrm{SDQ} \geq 100)$. In contrast, the group of European populations provided lower SDQ values $(100 \geq S D Q \geq 80)$, which indicates that they possess a more advanced enamel pattern. The molars of the two groups do not differ markedly in size.

\section{Würmian/Weichselian specimens}

Fossil molars of Würmian/Weichselian age come from Italy, Germany and France (data from Heinrich 1982, 1990a, Van Kolfschoten 1990, Desclaux et al. 2000). The French and the German Würmian/Weichselian sample clusters overlap; in contrast, the Italian group is more isolated, with only partial overlap with previous two (Text-fig. 11). The peninsular and the north-westernmost Italian (Ligurian) molars are large-sized $(3.90 \leq \mathrm{L} \leq 4.15)$ and have negative or undifferentiated enamel pattern $(113>\mathrm{SDQ}>98)$. A sort of morpho-geographical cline can be observed from the central-southern peninsula to the Liguria region; the latter specimens have more advanced enamel quotient $(100>$ SDQ $>98$ vs $113.5>$ SDQ $>108$, respectively). The centralsouthern Italian Würmian/Weichselian molars have SDQ values comparable to those of recent specimens, whereas the Ligurian specimens have more derived SDQ values, close or lower than those with undifferentiated pattern.

The French and German Würmian/Weichselian groups include molars with similar enamel characteristics: $99.96 \geq$
SDQ $\geq 78.4$ and 101.2 $\geq$ SDQ $\geq 83.1$ for French and German samples respectively. Also, the sizes are comparable, although an individual sample from Germany is significantly smaller (Burgtonna 2). There is partial overlap between the Würmian/Weichselian fossils from Germany and France and the composite group of recent "European" taxa (i.e., recent populations from Germany and Austria), but the former are larger sized and have somewhat more advanced enamel pattern.

\section{Eemian and early Würmian/Weichselian specimens}

This plot (Text-fig. 12) includes Arvicola from Eemian levels (MIS 5e) and from the other MIS 5 sub-stages that record the effects of the cool-warm fluctuations that preceded the first stadial of the MIS 4 glacial episode.

The Arvicola from the Italian localities (Scario A, Campania and Cucigliana, Tuscany) and the southern Italian populations of the last glacial cycle cluster close to one another and share similar size and SDQ values. The morphological similarity may reflect substantial continuity of the Eemian and Würmian/Weichselian Arvicola populations of the peninsula.

In contrast, the Eemian molars from Germany and France differ from their Würmian/Weichselian counterparts, by having less advanced enamel pattern and smaller size. The clusters overlap, but the French specimens have somewhat smaller SDQ values and size. The two groups, however, tend to form a rather homogenous cluster characterised at its extremes by SDQ and L values (109.6 $\geq$ SDQ $\geq 93.7$ and $3.73 \leq \mathrm{L} \leq 3.95$, respectively), clearly distinct from those of the Italian Peninsular specimens. A single sample from 


\section{Würmian Samples}

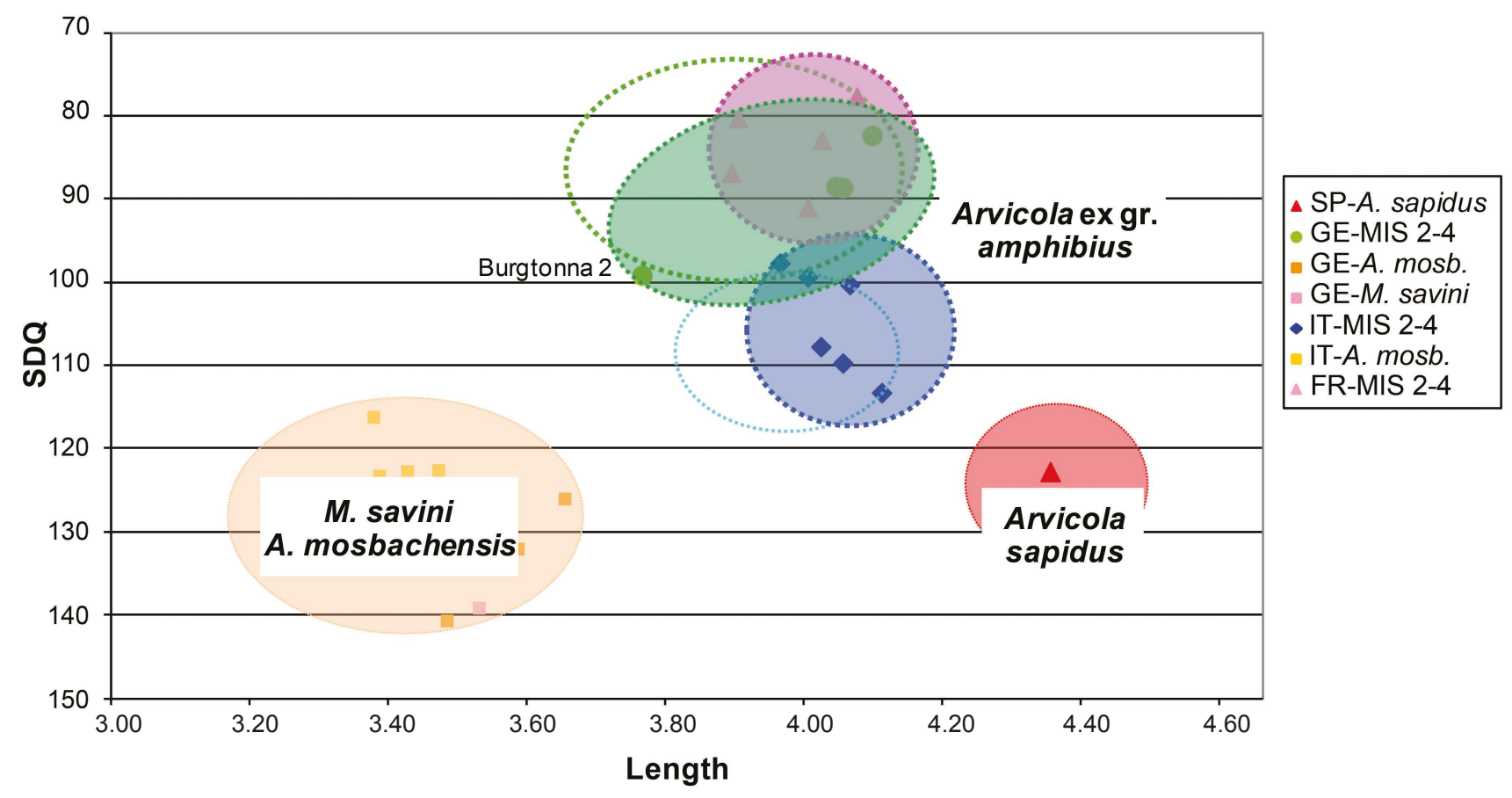

Text-fig. 11. Scatter diagram of $\mathrm{m} 1$ length vs SDQ for Würmian/Weichselian (time slice 3) Arvicola samples from different geographical provenances compared with $M$. savini-A. mosbachensis and extant Arvicola sapidus. Empty dotted ovals indicate the range of extant Arvicola ex gr. amphibius samples from Italy (cyan) and from the other European locations (green) Abbreviations: FR - France, GE - Germany, IT - Italy, SP - Spain.

Germany, (Burgtonna/Cm level), is distinctly separated from the others because of its very advanced enamel pattern $(\mathrm{SDQ}=78.9)$.

\section{Pre-Eemian (Saalian/Rissian sensu lato) specimens}

The ages of these specimens are more varied than the previous ones. This may be responsible of the greater morphological variation observable in the graph (Textfig. 13).

The two pre-Eemian molars from southern (Scario SG pit) and central (Campitello) Italy partially overlap (or are close to) the lower limits of the range of variability of the German and French water voles. They plot very close to the younger (Eemian and Würmian) Italian specimens. The result reinforces the hypothesis of continuity of the Arvicola lineage in this sub-region.

Nonetheless, the German and French clusters have rather heterogeneous size and enamel pattern. In particular, the two groups include molars with rather primitive and very advanced enamel quotient (113.9 $\geq$ SDQ $\geq 107.9$ and 94.2 $\geq \mathrm{SDQ} \geq 82.2$, respectively), whereas the size ranges from 3.7 to $4.21 \mathrm{~mm}$.

\section{Interpretation of the morpho-stratigraphical pattern}

Starting from the recent specimens, the results show that the so called Arvicola italicus lineage is morphologically fairly distinct from other European representatives $(A$. amphibius lineage). A similar situation is observed during the Würmian/Weichselian time slice, but with interesting differences. Compared to molars of living representatives, those of Würmian/Weichselian Arvicola are in general larger-sized and the specimens from Germany and France apparently tend to have a somewhat more advanced enamel pattern. In contrast, the Würmian/Weichselian teeth from southern Italy show the same range of enamel variation as the molars of living representatives. The Ligurian molars stand out by having more advanced SDQ values, close or overlapping those of the French and German specimens.

The situation is very different in the Eemian. The European A. amphibius water voles of this time period were smaller, on average, and had more primitive enamel pattern than the Würmian/Weichselian members. Representatives of the Italian Peninsula were already very large sized and had proportionally less advanced enamel differentiation. This data indicates that perhaps at least the A. italicus already existed during the Eemian warm period as a separated lineage, independent from that of A. amphibius. The latter group contains an outlier with rather advanced enamel quotient, represented by the water vole from the Burgtonna/ Cm level (Germany).

During the pre-Eemian Rissian/Saalian (s. 1.) time slice, French and German Arvicola specimens show rather varied sizes and enamel quotients. The outlying value of the Eemian vole from Burgtonna/Cm falls in the field of the highest values of the "Rissian/Saalian" European water voles. Despite its stratigraphic age, the Burgtonna/ $\mathrm{Cm}$ specimen could actually be a sort of holdover of the advanced "Rissian/Saalian" amphibius-like Arvicola in this central northern region of Europe. The two specimens from the Italian Peninsula (Campitello and Scario SG), on 


\section{Eemian Samples}

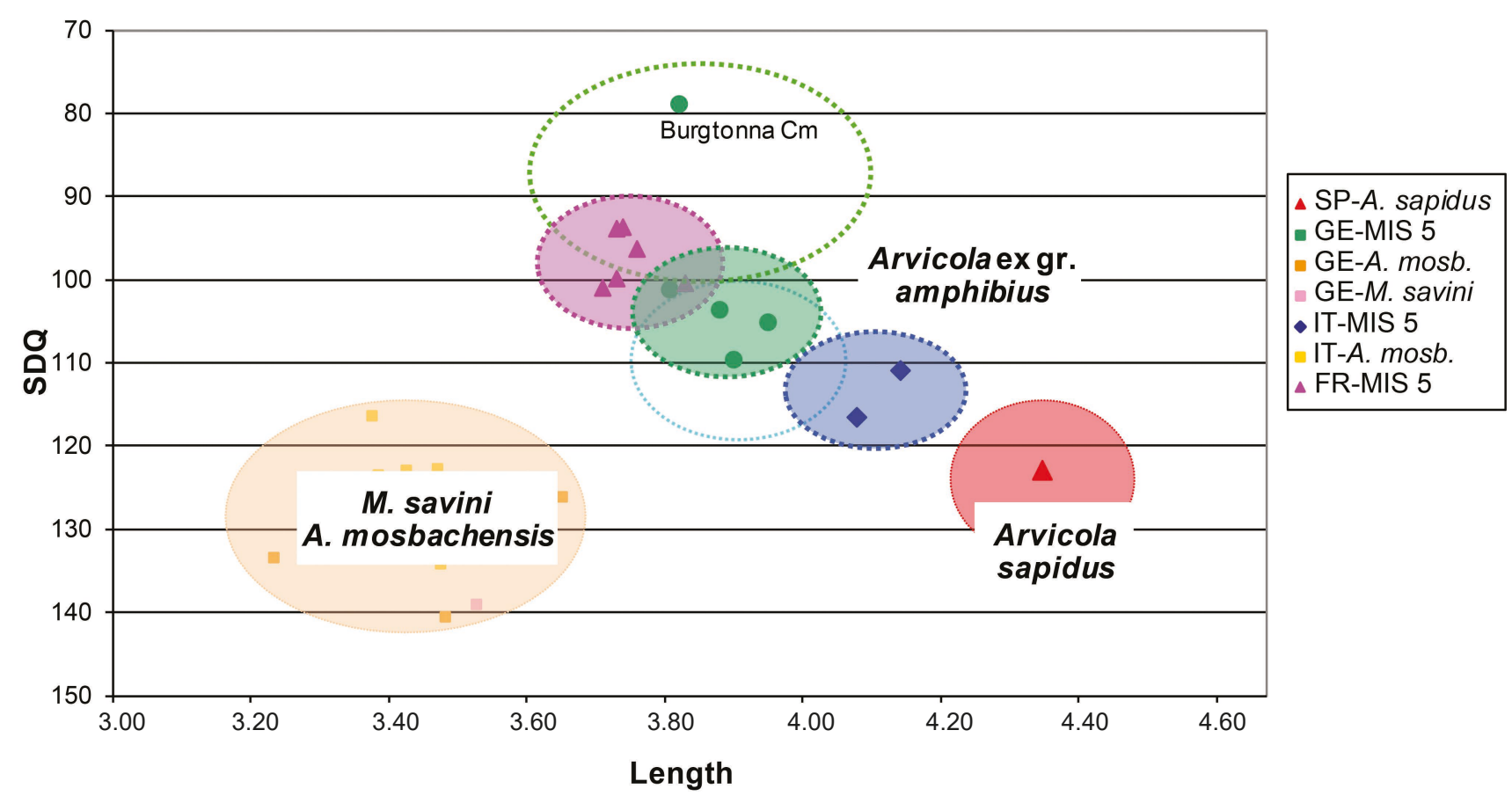

Text-fig. 12. Scatter diagram of $\mathrm{m} 1$ length vs SDQ for Eemian (time slice 4) Arvicola samples from different geographical provenances compared with M. savini-A. mosbachensis and Arvicola sapidus. Empty dotted ovals indicate the range of extant Arvicola ex gr. amphibius samples from Italy (cyan) and from the other European locations (green) Abbreviations: FR - France, GE - Germany, IT - Italy, SP - Spain.

\section{Pre-Eemian Samples}

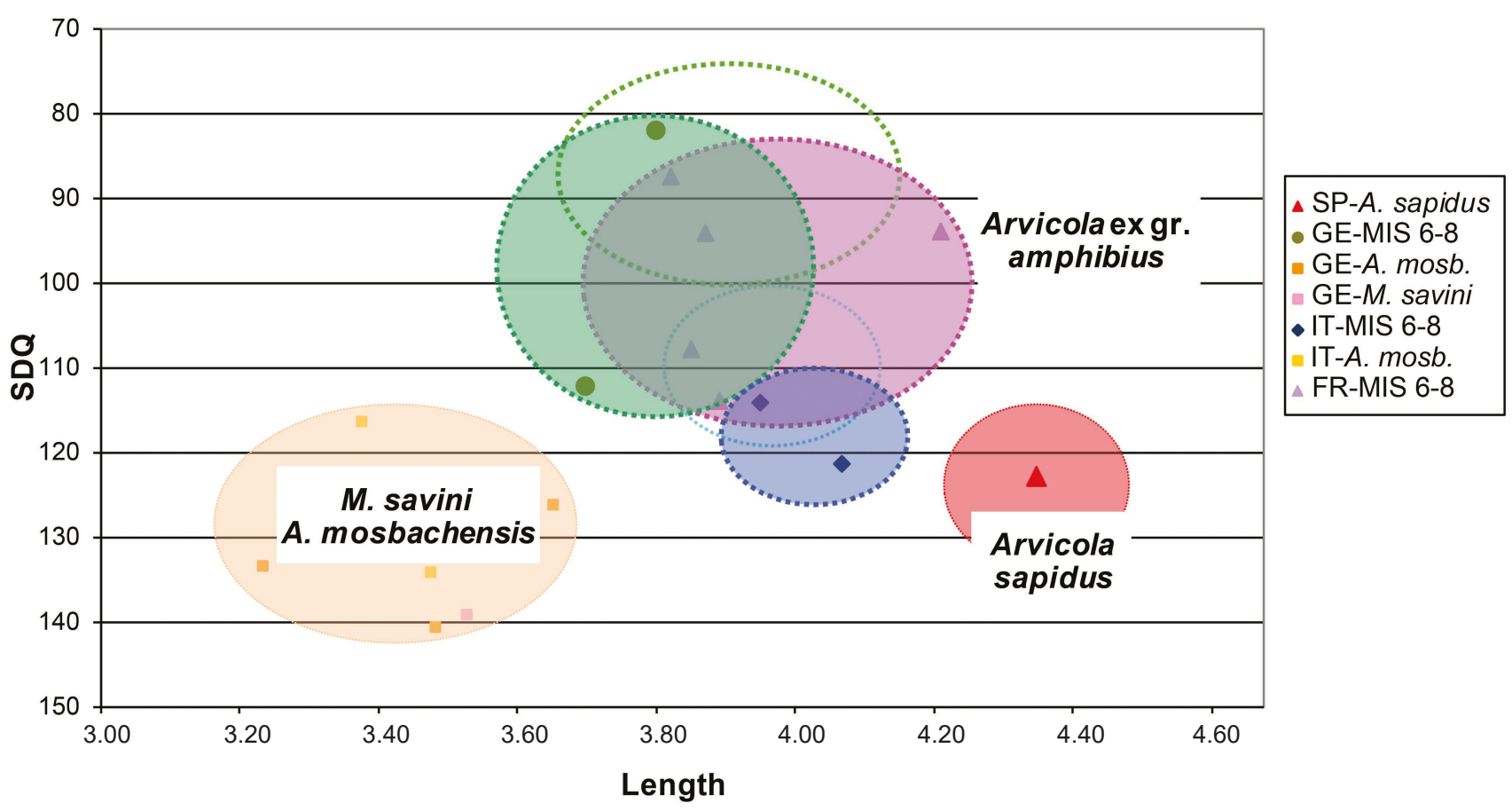

Text-fig. 13. Scatter diagram of $\mathrm{m} 1$ length vs SDQ for pre-Eemian (time slice 5) Arvicola samples from different geographical provenances compared with $M$. savini-A. mosbachensis and Arvicola sapidus. Empty dotted ovals indicate the range of extant Arvicola ex gr. amphibius samples from Italy (cyan) and from the other European locations (green) Abbreviations: FR - France, GE - Germany, IT - Italy, SP - Spain. 
the other hand, plot close to the range of variation of the "Eemian" Italian samples and tend to overlap the fields of the less advanced European voles. This morphological stability suggests phyletic continuity of the A. italicus lineage. Although less clear than that of the voles analysed so far, the status of the Rissian/Saalian Arvicola suggests that during the penultimate glacial cycle, some "protoamphibius" Arvicola population had already acquired an advanced enamel pattern analogous to that of the Würmian A. amphibius; the less advanced populations are in fact of older age (e.g., Ehringsdorf in Germany and Abri Gaudry in France). Alternatively, the advanced populations can be assumed to result from dispersal from North Eastern regions, where Arvicola had already achieved an advanced morphology.

\section{Discussion}

\section{The time of Mimomys savini-Arvicola mosbachensis transition in Italy}

The transition from rooted (M. savini) to rootless voles (Arvicola) is the so-called Mimomys/Arvicola boundary (Koenigswald and Van Kolfschoten 1996). The transition occurs in three stages: (1) Late populations of Mimomys savini, characterised by molars with clearly separated roots and with rootless teeth possessed only by juvenile individuals. Examples come from Voigtstedt, Süßenborn (both Germany) and West Runton (UK) (Kretzoi 1965, Fejfar 1969, Maul and Parfitt 2010). (2) The appearance of incipient roots (clear closure of the crown base) among predominantly rootless molars marks the advent of an ancient Arvicola (or transitional) population. However, distinctly separated roots have never been observed in transitional populations, such as Isernia, Mosbach, and Mauer (Koenigswald and Van Kolfschoten 1996, Maul et al. 2000). (3) Populations with exclusively rootless molars, undoubtedly typical of Arvicola.

The Italian site of Isernia was the first site where a very primitive Arvicola (stage 2) could be directly dated, yielding an Ar/Ar age of ca. $605 \mathrm{ka}$ (Coltorti et al. 2005). Later on, also the German site of Mauer was palaeontologically dated ca. $600 \mathrm{ka}$ (Wagner et al. 2011). Both sites therefore correlate with the MIS 15 interglacial.

Is this transition synchronous throughout Europe? A recent careful compilation by Mahmoudi et al. (2019) and Maul (2019) indicates that the transition from Mimomys savini to Arvicola occurred roughly at the same time in most places of Europe (except parts of Spain where Arvicola jacobaeus was distributed); dated finds of ancient Arvicola are reported from MIS 13. An unresolved issue is whether this is evidence of synchronous evolution (multiregional anagenetic process) or of a single evolutionary event followed by subsequent multiple immigrations.

\section{General and punctual inferences}

The pattern of morphological variation through time, seen so far in the molars analysed for this study, enables interesting inferences to the evolution of European water voles. With the large number of observations considered in this study, we can exclude that the enamel pattern of Arvicola evolved synchronously along a single, linear trend over the entire geographical range of the genus. Results show that there were at least two lineages of Arvicola in the European regions considered for this investigation: one in the Italian Peninsula and at least another one spread throughout Central and Western Europe.

It was Van Kolfschoten (1992), who first assumed that the evolutionary pattern of Arvicola is more intricate than it at first seemed, and that older populations of Arvicola (e.g., those of the time of the Rissian/Saalian glaciation, the ones from Ariendorf 2, Plaidter Humerich 1) have already acquired a more advanced enamel pattern than the Eemian ones. He explained this apparent evolutionary "reversal" with the re-immigration of more "primitive" Arvicola populations during warmer interglacials from their southern refuge areas. An unresolved issue is if and/or where, the evolved population survived during interglacials. The results of the present study indicate the presence of patchy, isolated, more advanced populations during the Eemian interglacial, possibly belonging to a third lineage, but the evidence is still largely circumstantial and inconclusive. In any case, these observations indicate that water voles underwent a complex history during the last two glaciations.

The results also hint that water vole populations/species may have been driven by climate-related changes. The possible influences of climatic drivers were analysed by Piras et al. (2012) using geometrical morphometrics on the shape and size of $\mathrm{m} 1$. The authors reached the conclusion that climate is just one of the factors that affect the morphology of the Arvicola dentition ("interspecific variation in shape is mostly correlated with climate" - Piras et al. 2012: 342). The results of the present study demonstrate that there are connections between the morphological variations in Arvicola and glacial/interglacial cycling; morphological variations are particularly strong during glacials. Climate perhaps acts on the dental morphology of water voles in a twofold manner. On the one hand, climate changes may trigger adaptive responses, such as, for instance, the variations in the enamel pattern, thus producing in situ evolutionary changes. The spread of arid steppes over large parts of Europe during glacial episodes, and the subsequent adaptation of water voles to the new landscapes, is a consequence of climatic deterioration. On the other hand, glacial cycles also force populations to migrate or, at least, to change their distribution ranges; allochthonous populations thus mix with resident ones and different morphologies forcefully coexist in the same geographical region.

Regions north of the Alpine chain are more exposed to severe climatic stress as well as to biotic influences from eastern and north-eastern regions; in fact, several "cold" mammalian taxa (both small and large mammals) spread to France and Germany during phases of climatic deterioration. The areal distribution of Arvicola extends considerably eastward, and it is likely that some populations migrated into central-western Europe during stadial phases, or at least that high rates of inbreeding were favoured between resident and immigrant populations. Noteworthy is that the populations of the Italian Peninsula were less exposed to these phenomena. Faunal influences from the other Eurasian regions are less 
intense in the Italian Peninsula; they are only observed in northeastern areas and in areas restricted to the north-west boundary. Conversely, both in the Italian Peninsula and in central and western Europe, more stable environmental conditions of interglacial cycles may be related to periods of reduced variability in the water vole populations. During interglacials, however, entire species, or populations more adapted to warm-temperate climates are expected to spread from their refuge areas.

The rather homogeneous features of Arvicola from the Italian Peninsula, which can be traced back to at least the "Rissian/Saalian" glaciation indicates that this water vole evolved in rather isolated conditions during the last two glacial cycles. The occurrence of the "primitive" A. italicus lineage is consistent with the model of the refuge areas, played by Mediterranean peninsulas - such as Italy (A. italicus) and Spain (A. sapidus), for temperate taxa. Morphological evidence excludes that the " $A$. italicus" water vole can be a potential re-colonizer during the last interglacial, because it is fairly different from the other members of the genus Arvicola also during the Eemian time slice.

The results of dental-morphological studies are substantially consistent with the phylogenetic-phylogeographic pattern inferred by Wust-Saucy (1998) and by Castiglia et al. (2016). These authors found the endemic species $A$. italicus distributed over almost the whole Italian Peninsula. The present work permits to trace the Italian lineage at least back to the penultimate glaciation. Older Arvicola specimens from the north-easternmost areas of the Italian territory do show all the features of A. mosbachensis; they show no trace of morpho-phyletic change leading to $A$. italicus. In our opinion they represent "true" A. mosbachensis. If the molecular clock indicates that the A. italicus lineage emerged earlier than the penultimate glaciation, it should have taken place in the peninsular territory and not in the north east of Italy. The present investigation did not find any evidence of the occurrence of $A$. "scherman" nor of A. monticola in the examined locations.

\section{Interpretation of the morphometric changes}

Arvicola shows morphometric changes in size. The A. amphibious-A. italicus species became increasingly larger, elongated the ACC, and reduced the relative thickness of convex enamel edges in upper and lower teeth.

Size is especially related to ecological preferences as well as to lifestyle habits (i.e., mountain dwelling species are smaller). Fossorial water voles are actually smaller than aquatic ones (see Cubo et al. 2006).

The relative thickness of enamel is a more complex question. Enamel differentiation seems not to be susceptible to evolutionary reversals. Trends observed in different regions can be the result of several "interferences", e.g., migrations from various regions of populations with different enamel quotient, altitude or dietary effects, different life histories. We still ignore if the trends evolved in response to adaptive needs. In his pioneering work Rensberger (1975) interpreted the development of asymmetric enamel wall thickness in the molars of fossorial rodents as an adaptation to chewing hard food. Maul et al. (2014) suggested that a switch to a fossorial habit, which involves chewing soil particles, could trigger the evolution of asymmetric enamel ratio in arvicolines. The question, however, is far from being settled.

Unlike Microtus, Arvicola shows minimum variation in the relative length of the ACC. Nonetheless, recent species/ populations tend to develop somewhat longer ACC. This was never observed before in water voles and requires further investigation to be confirmed. The elongation and increased complexity of ACC in $\mathrm{m} 1$, in M3 and the decrease of SDQ values in several species of Microtus seem to be correlated phenomena (Lippi et al. 1998). The significance of this trend is still not fully understood. Reduced thickness of trailing edges is related to thickened and hardened leading edges, which became more rapidly broken and abraded. One can speculate that a longer tooth with a greater number of protruding leading edges is more efficient in chewing hard food than a shorter molar with less protruding couples of edges in each dental triangle.

\section{Conclusions}

The morphometric-stratigraphical approach used to compare the records of extant and past Italian Arvicola with those from selected western and central European regions gave significant results. During the last two glaciations there were already at least two lineages of Arvicola in the geographical area selected for this study: a lineage of largesized peninsular Italian water voles with primitive SDQ values and at least a "North of the Alps" lineage possessing molars with a more advanced enamel pattern. During the Eemian and early Würmian/Weichselian the peninsular lineage is less well-defined and during the last glacial period, in north western Italy lived water voles with more advanced dental morphotypes. What all this delineates is a clinal variation, or a faunal exchange with the neighbouring French region.

The results of the morphological analysis conducted for this study are substantially in line with the phylogeneticphylogeographic pattern inferred by Wust-Saucy (1998) and by Castiglia et al. (2016) using molecular methods; according to the results obtained by these authors an endemic species, $A$. italicus, distinct from counterparts in other European areas, is distributed throughout almost all Italian Peninsula. In sum, the conclusions of the present analysis corroborate the results obtained by Maul et al. (1998b) and Masini et al. (2007).

Some reflections on the taxonomy and evolution of the genus Arvicola can be offered. The occurrence of directional trends in both Arvicola and M. savini indicate that channelled, parallel morphological changes play a significant role in the evolution of this clade of Arvicolinae. This mode of evolution has an unexpected bearing on our conception of phylogeny and taxonomy. Some authors (Cuenca-Bescós et al. 2010) included in genus Arvicola the species A.jacobaeus as possible sister group of all other Arvicola species. A.jacobaeus, however, is much older than the oldest Arvicola species, and had already developed rootless molars. Under this perspective, in a younger time period, the ancestral M. savini would originate independently $A$. mosbachensis and also other species of Arvicola. The resulting phylogenetic pattern would be polyphyletic and the stemming of several chrono-species from the same ancestor, with very complex relationships. Also, the apparently synchronic origin of the 
rootless Arvicola from M. savini in different geographical places would delineate an anagenetic mode of evolution; this would be in stark contrast to dichotomous cladogenetic models, which are the fundament of current taxonomy and systematics. The evolution of Arvicola has the potential for significant systematic theoretical developments.

A few words need to be said about the three chronospecies included in the lineage that leads to modern A. amphibius. Koenigswald and Van Kolfschoten (1996) focused on the variations in the enamel pattern of $\mathrm{ml}$ and proposed the following criteria to set specific boundaries between the various species: A. mosbachensis (SDQ > 120), A. mosbachensis/amphibius $(120<$ SDQ < 95) and A. amphibius (SDQ $<95)$. These distinctions are valid if Arvicola is assumed to form a single lineage. The varying SDQ values in other lineages of Arvicola argues against Koenigswald and Van Kolfschoten's (1996) criteria and calls for other standards to be defined to distinguish the different lineages.

This is even more important in the light of the results of the present study, which revealed also great morpho-dental variability in the molars of "north to the Alps" voles. Based on this it can be assumed that another advanced species in more northern and eastern regions of Eurasia dispersed episodically (during glacials) into central and western Europe, but without reaching the peninsular region of Italy.

This work shows how important it is to have a more complete geographic-stratigraphic-morphological picture of water voles. The scenario presented here certainly needs to be extended and completed, for instance extending our observations to A. monticola, the fourth species of European Arvicola, which was not included in the present analysis. Our knowledge of Arvicola populations from the Balkan Peninsula, now still quite imperfect, should also be improved. A careful study of the past and extant Balkan water vole Dinaromys, which is distributed both in the Balkans and in northern Italy, would be helpful for future comparative analyses.

\section{Acknowledgements}

We are indebted to the following colleagues who provided material and precious suggestions: Gerhard Storch ( $\dagger$ ) (Forschungsinstitut Senckenberg, Frankfurt a. M.), Mara Cagnin (Università di Calabria - recent populations from the Po Valley), Benedetto Sala (Università di Ferrara - material from Isernia La Pineta, 'La Serratura' cave/Campania, and Grotta del Romito/Calabria), Carmen Sesé (Museo Nacional Ciencias Naturales, material of Arvicola sapidus), Paolo Gambassini, Anna Maria Ronchitelli, Paolo Boscato (University of Siena, for the material of Castelcivita Cave/ Campania and of Grotta Grande di Scario/Campania), Carlo Tozzi, Giovanni Boschian (University of Pisa - for the material of Visogliano Shelter/Trieste). We are grateful to Paul P. A. Mazza, for critical reading of the manuscript and for checking the English language of the paper. Last but not least we thank the two reviewers Ivan Horáček (Prague) and László Kordos (Budapest) for critical reviews and suggestions, Jan Wagner and the whole editorial team of the journal Fossil Imprint for their great work.

\section{References}

Abbazzi, L., Fanfani, F., Ferretti, M. P., Rook, L., Cattani, L., Masini, F., Mallegni, F., Negrino, F., Tozzi, C. (2000): New Human Remains of Archaic Homo sapiens and Lower Palaeolithic Industries from Visogliano (Dusino Aurisina, Trieste, Italy). - Journal of Archaeological Science, 27: 1173-1186. https://doi.org/10.1006/jasc.1999.0541

Agnesi, V., Di Maggio, C., Macaluso, T., Masini, F., Petruso, D., Simonelli, C. (2000): Quaternary environmental climatic changes in Sicily. - Memorie Società Geologica Italiana, 55: 339-344.

Ambrosetti, P., Bartolomei, G., De Giuli, C., Ficcarelli, G., Torre, D. (1979): La breccia ossifera di Slivia (Aurisina-Sistiana) nel Carso di Trieste [The bone breccia of Slivian (Aurisina-Sistiana) in karst of Trieste]. - Bolletino della Società Paleontologica Italiana, 18(2): 207-220. (in Italian)

Azzaroli, A. (1977): The Villafranchian stage in Italy and the Plio-Pleistocene boundary. - Giornale di Geologia, 41(1-2): 61-79.

Azzaroli, A. (1998): Hystrix etrusca Bosco, the late Villafranchian porcupine from the Upper Valdarno, central Italy. - Palaeontographia Italica, 85: 177-198.

Bartolomei, G. (1980): Micromammiferi del Plio-Pleistocene [Micromammals from the Plio-Pleistocene]. - In: Parisi, G. (ed.), Vertebrate Fosili italiani. Catalogo della Mostra. Commune di Verna, Verona, pp. 249-258. (in Italian)

Bon, M., Piccoli, G., Sala, B. (1991): I giacimenti quaternari di vertebrati fossili nell'Italia nord-orientale [The Quaternary localities of fossil vertebrates in northeastern Italy]. - Memorie di Scienze Geologiche, 43: 185-231. (in Italian)

Bona, F., Sala, B., Tintori, A. (2008): Early Toringian small mammals fauna from Fontana Marella cave (Varese, Lombardy, North Italy). - Rivista Italiana di Paleontologia e Stratigrafia, 114(1): 133-144. https://doi.org/10.13130/2039-4942/6372

Bosco, C. (1898): Hystrix etrusca n. sp. - Palaeontographia Italica, 4: 141-154.

Bosco, C. (1899): I roditori Pliocenici del Valdarno superiore [Rodents in the Pliocene of the Upper Valdarno]. Palaeontographia Italica, 5: 85-104. (in Italian)

Breda, M., Marchetti, M. (2007): Pleistocene mammal faunas from the Leffe Basin (Bergamo, Northern Italy): Revision and new data. - In: Kahlke, R.-D., Maul, L. C., Mazza, P. P. A. (eds), Late Neogene and Quaternary biodiversity and evolution: Regional developments and interregional correlations, Volume II. Courier Forschungsinstitut Senckenberg, 259: 61-77.

Cagnin, M. (2008): Arvicola amphibius. - In: Amori, G., Contoli, L., Nappi, A. (eds), Mammalia II. Erinaceomorpha, Soricomorpha, Lagomorpha, Rodentia. Ministero dell'Ambiente e della Tutela del territorio, Calderin, Milano, pp. 445-458. (in Italian)

Castiglia, R., Aloise, G., Amori, G., Annesi, F., Bertolino, S., Capizzi, D., Mori, E., Colangelo, P. (2016): The Italian peninsula hosts a divergent mtDNA lineage of the water vole, Arvicola amphibius s. 1., including fossorial 
and aquatic ecotypes. - Hystrix, the Italian Journal of Mammalogy, 27(2): 1-5.

https://doi.org/10.4404/hystrix-27.2-11588

Catalisano, A., Sarà, M. (1995): L'Arvicola terrestris in Sicilia [Arvicola terrestris in Sicily]. - Atti Società Italiana di Scienze Naturali Museo Civico d Storia Naturale di Milano, 134(1): 8-12. (in Italian)

Cattani, L., Cremaschi, M., Ferraris, M. R., Mallegni, F., Masini, F., Scola, V., Tozzi, C. (1991): Le gisement du Pléistocène moyen de Visogliano (Trieste): restes humains, industries, environnement. - L'Anthropologie, 95(1): 9-36.

Coltorti, M., Ferraud, G., Marzoli, A., Peretto, C., Ton-That, T., Voinchet, P., Bahain, J.-J., Minelli, A., Thun-Hohenstein, U. (2005): New ${ }^{40} \mathrm{Ar} /{ }^{39} \mathrm{Ar}$ stratigraphic and paleoclimatic data on the Isernia La Pineta Lower Palaeolithic site, Molise, Italy. - Quaternary International, 131: 11-22. https://doi.org/10.1016/j.quaint.2004.07.004

Cubo, J., Ventura, J., Casinos, A. (2006): A heterochronic interpretation of the origin of diggin adaptation in the norther water vole, Arvicola terrestris (Rodentia: Arvicolidae). - Biological Journal of the Linnean Society, 87: 381-391. https://doi.org/10.1111/j.1095-8312.2006.00575.x

Cuenca-Bescós, G., Agustí, J., Lira, J., Rubio, M. M., Rofes, J. (2010): A new species of water vole from the Early Pleistocene of Southern Europe. - Acta Palaeontologica Polonica, 55(4): 565-580. https://doi.org/10.4202/app.2009.0027

Desclaux, E., Abbassi, M., Marquet, J.-C., Chaline, J., Van Kolfschoten, T. (2000): Distribution and evolution of Arvicola Lacépède, 1799 (Mammalia, Rodentia) in France and Liguria (Italy) during the Middle and the Upper Pleistocene. - Acta zoologica cracoviensia, 43(1-2): 107-125.

Di Canzio, E., Bedetti, C., Petronio, C., Sardella, R. (2003): Middle Pleistocene Vertebrate fauna from Cretone (Sabina, Latium). - Bollettino della Società Paleontologica Italiana, 42(1-2): 129-132.

Fanfani, F. (2000): Revisione degli insettivori (Mammalia) tardo neogenici e quaternari dell'Italia peninsulare [Revision of insectivores (Mammalia) from the late Neogene and Quaternary of the Italian Peninsula]; Ph.D. Thesis. - MS, Università di Bologna-Firenze-Modena-Roma 'La Sapienza, Italy, 282 pp. (in Italian) (copy in library of the Dpt. of Earth Science of the University of Florence, Italy)

Fejfar, O. (1969): Die Nager aus den Kiesen von Süßenborn bei Weimar. - Paläontologische Abhandlungen, Reihe A, 3(3-4): 761-770.

Fejfar, O. (1972): Die Wühlmäuse (Microtidae, Mammalia) der älteren Sammlungen aus Stránská skála bei Brno. Anthropos, 20(N.S. 12): 165-174.

Fejfar, O., Heinrich, W.-D., Lindsay, E. H. (1998): Updating the Neogene Rodent biochronology in Europe. - Mededelingen Nederlands Instituut voor Geowetenschappen TNO, 60: 533-554.

Gatta, M., Kotsakis, T., Pandolfi, L., Petronio, C., Salari, L., Achino, K. F., Silvestri, L., Rolfo, M. F. (1998): The Late Pleistocene faunal assemblage from Cava Muracci (Lati- um, Italy): Palaeoenvironmental implications for coastal central Italy during MIS 3. - Comptes Rendus Palevol, 18(1): 51-71.

https://doi.org/10.1016/j.crpv.2018.04.006

Gippoliti, S. (2012): The name of the Italian water vole Arvicola cf. amphibius (Linnaeus, 1758). - Hystrix, the Italian Journal of Mammalogy, 23(2): 87-89.

Giraudi, C., Mottura, A., Sala, B., Siori, M. S., Daniele, B. (2003): The Castagnone site (Cerrina Valley, Monferrato Hills, NW Italy): Early Pleistocene sedimentary record and biochronology. - Rivista Italiana di Paleontologiia e Stratigrafia, 109: 517-526. https://doi.org/10.13130/2039-4942/5520

Gliozzi, E., Abbazzi, L., Argenti, P., Azzaroli, A., Caloi, L., Capasso Barbato, L., Di Stefano, G., Esu, D., Ficcare1li, G., Girotti, O., Kotsakis, T., Masini, F., Mazza, P. P. A., Mezzabotta, C., Palombo, M. R., Petronio, C., Rook, L., Sala, B., Sardella, R., Zanalda, E., Torre, D. (1997): Biochronology of selected mammals, molluscs and ostracods from the middle Pliocene to the late Pleistocene in Italy. The state of the art. - Rivista Italiana di Paleontologia e Stratigrafia, 103: 369-388.

Heinrich, W.-D. (1978): Zur biometrischen Erfassung eines Evolutionstrends bei Arvicola (Rodentia, Mammalia) aus dem Pleistozän Thüringens. - Säugetierkundliche Informationen, 2: 3-21.

Heinrich, W.-D. (1982): Zur Evolution und Biostratigraphie von Arvicola (Rodentia, Mammalia) im Pleistozän Europas. - Zeitschrift für geologische Wissenschaften, 10: $683-735$.

Heinrich, W.-D. (1987): Neue Ergebnisse zur Evolution und Biostratigraphie von Arvicola (Rodentia, Mammalia) im Quartär Europas. - Zeitschrift für geologische Wissenschaften, 15(3): 389-406.

Heinrich, W.-D. (1990a): Review of fossil arvicolids (Mammalia, Rodentia) from the Pliocene and Quaternary in the German Democratic Republic. - In: Fejfar, O., Heinrich, W.-D. (eds), International Symposium Evolution, Phylogeny, Biostratigraphy of Arvicolids (Rodentia, Mammalia) in Rohanov, May 1987. Geological Survey, Verlag Dr. Friedrich Pfeil, Prague, Munich, pp. 183-200.

Heinrich, W.-D. (1990b): Some aspects of the Evolution and Biostratigraphy of Arvicola (Mammalia, Rodentia) in the Central European Pleistocene. - In: Fejfar, O., Heinrich, W.-D. (eds), International Symposium Evolution, Phylogeny, Biostratigraphy of Arvicolids (Rodentia, Mammalia) in Rohanov, May 1987. Geological Survey, Verlag Dr. Friedrich Pfeil, Prague, Munich, pp. $165-180$.

Heller, F. (1933): Die Wühlmäuse der Mosbacher Sande. Notizblatt des Vereins für Erdkunde und Hessische Geologische Landesanstalt, für 1931/1932, V. Folge, 14: 108-116 + Taf. 110 .

Heller, F. (1958): Eine neue altquartäre Wirbeltierfauna von Erpfingen (Schwäbische Alb). - Neues Jahrbuch für Geologie und Paläontologie, Abhandlungen, 107: 1-102.

Hinton, M. A. C. (1926): Monograph of voles \& lemmings (Microtinae). Living and extinct. Vol. I. - British Museum, Natural History, London, 488 pp. +15 pls.

Koenigswald, W. v. (1970): Mittelpleistozäne Kleinsäugerfauna aus der Spaltenfüllung Petersbuch bei Eichstätt. - 
Mitteilungen der Bayerischen Staatssammlung für Paläontologie und historische Geologie, 10: 407-432.

Koenigswald, W. v. (1980): Schmelzstruktur und Morphologie in den Molaren der Arvicolidae (Rodentia). Abhandlungen der Senckenbergischen Naturforschenden Gesellschaft, 539: 1-129

Koenigswald, W. v. (1982): Zum Verständnis der Morphologie der Wühlmausmolaren (Arvicolidae, Rodentia, Mammalia). - Zeitschrift für Geologische Wissenschaften, 10(7): 951-962.

Koenigswald, W. v., Heinrich, W.-D. (1999): Mittelpleistozäne Säugetierfaunen aus Mitteleuropa - der Versuch einer biostratigraphischen Zuordnung. - Kaupia - Darmstädter Beiträge zur Naturgeschichte, 9: 53-112.

Koenigswald, W. v., Van Kolfschoten, T. (1996): The MimomysArvicola boundary and the enamel thickness quotient (SDQ) of Arvicola as stratigraphic markers in the Middle Pleistocene. - In: Turner, C. (ed.), The early Middle Pleistocene in Europe. A. A. Balkema, Rotterdam, pp. 211-226. https://doi.org/10.1201/9781003077879-15

Kotsakis, T., Abbazzi, L., Angelone, C., Argenti, P., Barisone, G., Fanfani, F., Marcolini, F., Masini, F. (2003): Plio-Pleistocene biogeography of Italian mainland micromammals. - Deinsea, 10: 313-342.

Kratochvíl, Z. (1981): Arvicola cantiana vit-elle encore? Folia Zoologica, 30(4): 289-300.

Kretzoi, M. (1965): Die Nager und Lagomorphen von Voigtstedt in Thüringen und ihre chronologische Aussage. Paläontologische Abhandlungen, Abteilung A, 2(2-3): 585-661.

Kryštufek, B. (2017a): Eurasian Water Vole Arvicola amphibius. - In: Wilson, D. E., Lacher, T. E. J., Mittermeier, R. A. (eds), Handbook of the Mammals of the World. 7. Rodents II. Lynx Edicion, Barcelona, p. 317.

Kryštufek, B. (2017b): Montane Water Vole Arvicola monticola. - In: Wilson, D. E., Lacher, T. E. J., Mittermeier, R. A. (eds), Handbook of the Mammals of the World. 7. Rodents II. Lynx Edicion, Barcelona, pp. 317-318.

Kryštufek, B. (2017c): South-western Water Vole Arvicola sapidus. - In: Wilson, D. E., Lacher, T. E. J., Mittermeier, R. A. (eds), Handbook of the Mammals of the World. 7. Rodents II. Lynx Edicion, Barcelona, pp. 316-317.

Kryštufek, B., Koren, T., Engelberger, S., Horváth, G. F., Purger, J. J., Arslan, A., Chişamera, G., Murariu, D. (2015): Fossorial morphotype does not make a species in water voles. - Mammalia, 79: 293-303.

https://doi.org/10.1515/mammalia-2014-0059

Lapini, L., Paolucci, P. (1994): Arvicola terrestris scherman (Shaw, 1801) in North-Eastern Italy (Mammalia, Arvicolidae). - Bollettino del Museo civico di storia naturale di Venezia, 43: 231-234.

Lippi, P., Masini, F., Maul, L., Abbazzi, L. (1998): Evolutionary changes of enamel differentiation in Pleistocene Mediterranean and Middle European populations of Microtus (Rodentia, Arvicolidae). - Paludicola, 2(1): 50-61.

López-García, J. M., Berto, C., Luzi, E., Dalla Valle, C., Banuls-Cardona, S., Sala, B. (2015): The genus Iberomys (Chaline, 1972) (Rodentia, Arvicolinae, Mammalia) in the Pleistocene of Italy. - Italian Journal of Geosciences, 134(1): 162-169.

https://doi.org/10.3301/IJG.2014.48
López-García, J. M., Blain, H. A., Pagano, E., Ollè, A., Vergès, J. M., Forgia, V. (2013): The small mammals (insectivores, bats and rodents) from the Holocene archaeological site of Vallone Inferno (Scillato, Lower Imera Valley, Northwestern Sicily). - Rivista Italiana di Paleontologia e Stratigrafia, 119: 229-244.

Mahmoudi, A., Maul, L. C., Khoshyar, M., Darvish, J., Aliabadian, M., Kryštufek, B. (2019): Evolutionary history of Water voles revisited: confronting a new phylogenetic model from molecular data with the fossil record. Mammalia, 84(2): 171-184. https://doi.org/10.1515/mammalia-2018-0178

Marcolini, F. (2002): Continental Lower Valdarno rodent biochronology and two new methods for the systematics of Mimomys (Arvicolidae, Rodentia); Ph.D. Thesis. - MS, Università di Pisa, 165 pp. (copy in library of the University of Pisa)

Marcolini, F., Bigazzi, G., Bonadonna, F. P., Centamore, E., Cioni, R., Zanchetta, G. (2003): Tephrochronology and tephrostratigraphy of two Pleistocene continental fossiliferous successions from central Italy. - Journal of Quaternary Science, 18(6): 545-556. https://doi.org/10.1002/jqs.768

Marcolini, F., Zanchetta, G., Bonadonna, F. P. (2000): Some preliminary data on two small mammal bearing paleosols from the Tyrrhenian and Adriatic sides of Italy. Oryctos, 3: 85-94.

Martin, R. A. (1987): Notes on the classification and evolution of some North American fossil Microtus (Mammalia; Rodentia). - Journal of Vertebrate Paleontology, 7(3): 270-283.

Martin, R. A., Tesakov, A. S. (1998): Introductory remarks: does Allophaiomys exist? - Paludicola, 2(1): 1-7.

Masini, F., Abbazzi, L., Lippi, P., Sala, B., Torre, D. (1998): Review and new finds of Microtus (Allophaiomys) (Rodentia, Arvicolidae) from the Early Pleistocene of the Italian Peninsula. - Paludicola, 2(1): 78-90.

Masini, F., Giannini, T., Abbazzi, L., Fanfani, F., Delfino, M., Maul, L. C., Torre, D. (2005): A latest Biharian small vertebrate fauna from the lacustrine succession of San Lorenzo (Sant'Arcangelo Basin, Basilicata, Italy). Quaternary International, 131: 79-93.

https://doi.org/10.1016/j.quaint.2004.07.008

Masini, F., Giannini, T., Abbazzi, L., Fanfani, F., Delfino, M., Torre, D. (2000): A small mammal fauna from the lacustrine succession of San Lorenzo (Sant'Arcangelo basin, Basilicata) and remarks on Pleistocene rodent chronology. - In: Abstracts, Meeting of the SEQS “The Plio-Pleistocene boundary and the Lower/Middle Pleistocene transition: type areas and sections", September 25-29 2000, Bari, Italy, p. 52.

Masini, F., Maul, L. C., Abbazzi, L., Petruso, D. (2007): New Data on the Morphological Variation of Extant and Fossil European Populations of Arvicola (Rodentia). In: Prigioni, C., Sforzi, A. (eds), Abstracts, V European Congress of Mammalogy, Part III: Rodents and Lagomorphs. Hystrix - Italian Journal of Mammalogy (n. s.), 18(Suppl.): 125.

Masini, F., Rook, L., Abbazzi, L., Ambrosetti, P., Azzaroli, A., Ficcarelli, G., Gentili, S., Kotsakis, T., Sala, B., Torre, D. (1996): Mammalian faunas of selected 
Villafranchian localities of Italy. - In: Carraro, F. (ed.), Revisione del Villafranchiano nell'area tipo di Villafranca d'Asti [The Villafranchian in the Villafranca d'Asti type-area: a revision]. Il Quaternario, 9(1): pl. 2.

Masini, F., Sala, B. (2007): Large- and small-mammal distribution patterns and chronostratigraphic boundaries from the Late Pliocene to the Middle Pleistocene of the Italian peninsula. - Quaternary International, 160: 43-56. https://doi.org/10.1016/j.quaint.2006.09.008

Masini, F., Santini, G. (1991): Microtus (Allophaiomys) from Cava Pirro (Apricena, Gargano) and other Italian localities. - Bollettino della Società Paleontologica Italiana, 30: 355-380.

Maul, L. C. (2001): Transition from hypsodonty to hypselodonty in the Mimomys savini-Arvicola lineage. - Lynx, n. s., 32: 247-253.

Maul, L. C. (2019): Die Kleinsäugerfauna aus der Forschungsbohrung Ummendorf 1/2012. - Mitteilungen zu Geologie und Bergwesen von Sachsen-Anhalt, 20: 99-108.

Maul, L. C., Masini, F., Abbazzi, L., Turner, A. (1998a): Geochronological application of evolutionary trends in the dentition of fossil Arvicolidae. - Mededelingen Nederlands Instituut voor Geowetenschappen TNO, 60: 565-572.

Maul, L. C., Masini, F., Abbazzi, L., Turner, A. (1998b): The use of different morphometric data for absolute age calibration of some South and Middle European arvicolid populations. - Palaeontographia Italica, 85: 111-151.

Maul, L. C., Masini, F., Parfitt, S. A., Rekovets, L. I., Savorelli, A. (2014): Evolutionary trends in arvicolids and the endemic murid Mikrotia - New data and a critical overview. - Quaternary Science Reviews, 96: 240-258. https://doi.org/10.1016/j.quascirev.2013.09.017

Maul, L. C., Parfitt, S. A. (2010): Micromammals from the 1995 Mammoth Excavation at West Runton, Norfolk, UK: Morphometric data, biostratigraphy and taxonomic reappraisal. - Quaternary International, 228: 91-115. https://doi.org/10.1016/j.quaint.2009.01.005

Maul, L. C., Rekovets, L. I., Heinrich, W.-D., Keller, T., Storch, G. (2000): Arvicola mosbachensis (Schmidtgen 1911) of Mosbach 2: a basic sample for the early evolution of the genus and a reference for further biostratigraphical studies. - Senckenbergiana lethaea, 80(1): 129-147. https://doi.org/10.1007/BF03043667

Mazza, P. P. A., Martini, F., Sala, B., Magi, M., Colombini, M. P., Giachi, G., Landucci, F., Lemorini, C., Modugno, F., Ribechini, E. (2006): A new Palaeolithic discovery: tar-hafted stone tools in a European Mid-Pleistocene bone-bearing bed. - Journal of Archaeological Science, 33: $1810-1818$. https://doi.org/10.1016/j.jas.2006.01.006

Milli, S., Palombo, M. R. (2005): The high-resolution sequence stratigraphy and the mammal fossil record: A test in the Middle-Upper Pleistocene deposits of the Roman Basin (Latium, Italy). - Quaternary International, 126: 251-270. https://doi.org/10.1016/j.quaint.2004.04.025

Pasa, A. (1947): I Mammiferi di alcune antiche brecce Veronesi [The mammals of some ancient breccias from Vero- na]. - Memorie della Museo Civico Storio Nazionale di Verona, 1: 1-111. (in Italian)

Piras, P., Marcolini, F., Claude, J., Ventura, J., Kotsakis, T., Cubo, J. (2012): Ecological and functional correlates of molar shape variation in European populations of Arvicola (Arvicolinae, Rodentia). - Zoologischer Anzeiger A Journal of Comparative Zoology, 251: 335-343. https://doi.org/10.1016/j.jcz.2011.12.002

Rensberger, J. M. (1975): Function in the cheek-tooth evolution of some hypsodont Geomyoid rodents. - Journal of Paleontology, 49(1): 10-22.

Rook, L., Martínez-Navarro, B. (2010): Villafranchian: The long story of a Plio-Pleistocene European large mammal biochronologic unit. - Quaternary International, 219: 134-144. https://doi.org/10.1016/j.quaint.2010.01.007

Röttger, U. (1986): Schmelzbandbreiten an Molaren der Gattung »Arvicola« LACÉPÈDE, 1799; Ph.D. Thesis. MS, Rheinische-Friedrichs-Wilhelms-Universität Bonn, Bonn, Germany, 121 pp. (copy in library of the University of Bonn)

Röttger, U. (1987): Schmelzbandbreiten an Molaren von Schermäusen (Arvicola LACÉPÈDE, 1799). - Bonner zoologische Beiträge, 38: 95-105.

Sala, B. (1990): Loess fauna in deposits of shelters and caves in the Veneto region and examples in other region of Italy. - In: Cremaschi, M. (ed.), The loess in Northern and Central Italy. Quaderni di Geodinamica Alpina e Quaternaria 1: 139-149.

Sala, B. (1999): Nuovi dati sulla microteriofauna di Notarchirico [New data on the small mammal faunas from Notarchirico]. - In: Piperno, M. (ed.), Notarchirico un sito del Pleistocene medio iniziale nel bacino di Venosa (Basilicata) [Notarchirico site from the beginning of the Middle Pleistocene in the Venosa Basin (Basilicata)]. Ediz. Osanna per Soprintendenza speciale al Museo Nazionale di. Preistoria e Etnografia 'L. Pigorini', Roma, pp. 439-441. (in Italian)

Sala, B. (2003): L'Italia del Nord-Est, ponte fra il Bacino Pannonico e il Mediterraneo occidentale [Northeaster Italy, a bridge between the Pannonic Basin and the western Meditarranean]. - In: Ferrara, U. d. (ed.), Atti in commemorazione di Edoardo Semenza. Università di Ferrara, Ferrara, pp. 203-208. (in Italian)

Sala, B., Marchetti, M. (2004): The Po Valley floodplain (northern Italy): a transitional area between two bioprovinces during the Late Neogene and Quaternary. - In: Maul, L. C., Kahlke, R.-D. (eds), $18^{\text {th }}$ International Senckenberg Conference 2004 in Weimar. Terra Nostra, 2004(2): 224.

Sala, B., Marchetti, M. (2006): The Po Valley floodplain (Northern Italy): A transitional area between two zoogeographical areas during the Late Neogene and Quaternary. - Courier Forschungsinstitut Senckenberg, 256: 321-328.

Sala, B., Masini, F. (2007): Late Pliocene and Pleistocene small mammal chronology in the Italian peninsula. Quaternary International, 160: 4-16. https://doi.org/10.1016/j.quaint.2006.10.002

Siori, M. S., Sala, B. (2007): The mammal fauna from the late Early Biharian site of Castagnone (Northern Mon- 
ferrato, Piedmont, NW Italy). - Geobios, 40: 207-217. https://doi.org/10.1016/j.geobios.2006.05.005

Stehlin, H. G. (1930): Die Säugetierfauna von Leffe. - Eclogae Geologicae Helvetiae, 23(2): 648-681.

Taberlet, P., Fumagalli, L., Wust-Saucy, A.-G. (1998): Comparative phylogeography and postglacial colonization routes in Europe. - Molecular Ecology, 7: 453-464. https://doi.org/10.1046/j.1365-294x.1998.00289.x

Tagliacozzo, A. (1993): Archeozoologia della Grotta Dell'Uzzo, Sicilia. Da un'economia di caccia ad un'economia di pesca ed allevamento [Archaeozoology of the Cave dell'Uzzo, Sicily. From a hunting economy to economy of fishing and farming]. - Istituto Poligrafico e Zecca dello Stato, Roma, 278 pp. (in Italian)

Torre, D. (1985): Mimomys savini and Arvicola cantiana in the Upper Valdarno (Italy). - Eclogae Geologicae Helvetiae, 78(3): 715-718.

Torre, D., Albianelli, A., Bertini, A., Ficcarelli, G., Masini, F., Napoleone, G. (1996): Paleomagnetic calibration of Plio-Pleistocene mammal localities in central Italy. - In: Nadachowski, A., Werdelin, L. (eds), Neogene and Quaternary Mammals of the Palaearctic. Papers in mammal palaeontology honoring Kazimierz Kowalski. Acta zoologica cracoviensia, 39(1): 559-570.

Toschi, A. (1965): Fauna d'Italia. Vol. VII. Mammalia: Lagomorpha - Rodentia - Carnivora - Ungulata - Artiodactyla - Cetacea. - Edizioni Calderini, Bologna, ix + $647 \mathrm{pp}$.
Van der Meulen, A. J. (1973): Middle Pleistocene Smaller Mammals from the Monte Peglia (Orvieto, Italy) with Special Reference to the Phylogeny of Microtus (Arvicolidae, Rodentia). - Quaternaria, 17: 1-144.

Van Kolfschoten, T. (1990): The evolution of the mammal fauna in The Netherlands and the middle Rhine Area (Western Germany) during the late Middle Pleistocene. - Mededelingen Rijks Geologische Dienst, 43: 1-69.

Van Kolfschoten, T. (1992): Aspects of the migration of mammals to northwestern Europe during the pleistocene, in particular the reimmigration of Arvicola terrestris. Courier Forschungsinstitut Senckenberg, 153: 213-220.

Wagner, G. A., Maul, L. C., Löscher, M., Schreiber, H. D. (2011): Mauer - the type site of Homo heidelbergensis: Palaeoenvironment and age. - Quaternary Science Reviews, 30: 1464-1473. https://doi.org/10.1016/j.quascirev.2010.01.013

Wilson, D. E., Reeder, D. M. (eds) (2005): Mammal Species of the World. A Taxonomic and Geographic Reference ( $3^{\text {rd }}$ ed.) $[2$ vols]. - Johns Hopkins University Press, Baltimore, 2, $142 \mathrm{pp}$.

Wust-Saucy, A.-G. (1998): Polymorphisme genetique et phylogeographie du campagnol terrestre Arvicola terrestris; Ph.D. Thesis. - MS, Université de Neuchatel, Lausanne, Switzerland, 178 pp. (copy in library of the Universiy of Neuchatel). 


\section{Appendix A}

This appendix contains a list in which each locality is mentioned in its stratigraphical-chronological frame and - if necessary - shortly discussed.

\section{Fossil record}

The Mimomys savini samples came from two deposits of different ages: Untermassfeld is a late Early Pleistocene site, dated at about 1.0 Ma (Wiegank 1997), whereas Voigtstedt is a Middle Pleistocene locality dated at about $0.7 \mathrm{Ma}$, containing a very hypsodont population of M. savini (Maul and Parfitt 2010).

The Arvicola mosbachensis set includes eight Middle Pleistocene samples from different geographical locations. The material from Isernia La Pineta (Sala 1996) has been shortly discussed in section "Arvicola mosbachensis": it represents one of the oldest Arvicola mosbachensis finds (dated at about $0.6 \mathrm{Ma}$ ) so far known. As shown in map (Textfig. 4: no. 19), Isernia is located within the Apennine chain and is the southernmost $A$. mosbachensis site considered here. The site of Visogliano is located in north-eastern Italy, near the town of Trieste. The documentation of the extensive small mammal material recovered during archaeological excavations is carried out by the Pisa University (Abbazzi et al. 2000, Falguères et al. 2008). It includes several taxa, which are indicative of the eastern and central European affinity of the fauna. The three samples considered are from different stratigraphic levels, spanning from about 0.5 to $0.25 \mathrm{Ma}$. Details on stratigraphy and on mammalian fauna are reported in Abbazzi et al. (2000) and Maul et al. (1998).

The other Arvicola mosbachensis samples came from four Middle Pleistocene sites in Germany.

Mosbach 2 (Maul et al. 2000) is the type locality of the species. The site of Mauer contains an Arvicola sample, the morphology of which is very similar to the finds of Mosbach, and is dated biochronologically and radiometrically to about 0.6-0.55 Ma (Wagner et al. 2010, 2011). It is thus coeval with Isernia. Also Miesenheim 1 is presumably of the same age (Van Kolfschoten 1990, Koenigswald and Van Kolfschoten 1996), whereas Petersbuch 1 is somewhat younger (Koenigswald 1970, 1973), roughly coeval with the two older stratigraphical levels in Visogliano (Visogliano B and Visogliano A-LL). Bilzingsleben 2 has to be placed to the Holsteinian interglacial/MIS 9 (Mania 1983, 1997, Heinrich 1990, Vlček et al. 2002).

The fossil Arvicola amphibius (= terrestris) group is represented by 35 samples spanning from the late Middle Pleistocene to the Holocene from different geographical locations in Italy, Germany and France. The samples from the Italian territory can be divided into three geographic subgroups: Italian Peninsular, Italian north-east and Italian northwest ones. The most conspicuous sub-group is composed by remains from 5 sites located at the western side of the central and southern Peninsula (Campania and Tuscany). The oldest sample are those from the pre-Tyrrhenian (= preEemian) level SG of Scario pit, and from Campitello (Upper Valdarno, identifyied as A. mosbachensis "evolved form" by Mazza et al. (2006)). Other two samples are referred to the Eemian - early Würmian/Weichselian: Scario Pit A (Abbazzi and Masini in Ronchitelli 1998, Ronchitelli et al. 2011) and Cucigliana (near the town of Pisa) (Acconci 1880, Farina 2011). Castelcivita Cave in Campania (Cioni et al. 1980, Masini and Abbazzi 1997, Gambassini 1997) dates to the Würmian inter-pleniglacial (MIS 3, 30-40 kyrs conventional ${ }^{14} \mathrm{C}$ dating), the sample from Serratura Cave layer 18c (Campania) (Bertolini et al. 1996) slightly predates the Late Glacial, whereas the sample from levels D9 to D34 of Grotta del Romito (López-García et al. 2014) dates ca. $12,170 \pm 60$ to $12,970 \pm 150,{ }^{14} \mathrm{C}$ yr. To this sub-group also the Holocene sample from Scario/Roman Levels (a single specimen) could be added. All the material is derived from archaeological excavations. The north-eastern sub-group includes Arvicola remains from the early Holocene levels at Grotta degli Orsi (Trieste, close to nowadays Slovenian border) (Boschian 1992, Boschian et al. 1996, Boschian and De Santis 2011, Berto and Rubinato 2013, and this paper).

Eventually, the north-western sub-group includes samples from two Cave deposits in Liguria, (Arma delle Manie and Riparo Mochi) which date to the early Würm (MIS 4) and to the Würmian inter-pleniglacial (MIS 3); measurements and age reference are from Desclaux et al. (2000).

The samples from the German sites are more evenly distributed. The remains from Ehringsdorf(Jánossy 1975) and Plaidter-Hummerich 1 (Van Kolfschoten 1990) are the oldest in this group, dated to the Saalian glacial or an intra-Saalian interglacial respectively. Burgtonna/Hy (early Weichselian Hystrix horizon), and Burgtonna/Cm (Eemian Cricetus major horizon) (Maul 1994), Taubach (Heinrich and Jánossy 1977), Stuttgart-Untertürkheim and Parkhöhle (Weimar) (Heinrich 1981, 1987) represent Arvicola samples dated to the Eemian interglacial; samples from the sites Euerwanger Bühl, Kemathenhöhlee, Krockstein (Rübeland 1) (Heinrich 1981, 1987) and Burgtonna level 2 are of Würmian age, while Pisede (Heinrich and Maul 1983) is of Holocene age.

The information about the French samples is compiled from Abbassi and Desclaux (1996) and Desclaux et al. (2000) to whom the reader is addressed for further information.

Eleven samples are considered, coming from excavations (mainly archaeological) in caves and shelters in 8 geographic locations from three geographical regions of the French territory. South-east France sites (Lazaret cave, Pie Lombard) are close to the Mediterranean Sea, and to the Italian border, to eastern France (Gigny Cave and MoulaGuercy Cave) and to western France (Suard Cave, Artenac Cave, Gaudry Cave, Vaufrey Cave, Eglise Cave).

\section{Recent samples of Arvicola amphibius/italicus}

Recent Arvicola samples from the Italian Peninsula came from the Po Valley (Delta Po, Rovigo, Ferrara) and from Calabria. Some other sporadic samples (composed by a single specimen) are from Bologna, Osnago (Como) and from the coast of Western Tuscany (locality Massaciuccoli - Pisa).

The recent samples from other European localities include two samples from the German territory (from Eisfeld/Thuringia (Frahnert 1991) and from Langen/Hassia), one for Austria (Rabwitz, close to the town of Graz). Further samples, composed by a single specimen, are from Geneve (Swiss) and from the French region of Isère. Eventually a sample of Arvicola sapidus from the surroundings of Madrid (this paper) has been also included in the comparisons. 


\section{References}

Abbassi, M., Desclaux, E. (1996): Arvicola LaCÉPÈDE, 1799 (Rodentia, Mammalia) de quatre sequences du sud-est de la France et de Ligurie datant de la fin du Pleistocene moyen et du debut du Pleistocene superieur. - Quaternaria, 7(1): 29-37. https://doi.org/10.3406/quate.1996.2055

Abbazzi, L., Fanfani, F., Ferretti, M. P., Rook, L., Cattani, L., Masini, F., Mallegni, F., Negrino, F., Tozzi, C. (2000): New Human Remains of Archaic Homo sapiens and Lower Palaeolithic Industries from Visogliano (Dusino Aurisina, Trieste, Italy). - Journal of Archaeological Science, 27: 1173-1186.

https://doi.org/10.1006/jasc.1999.0541

Acconci, L. (1880): Sopra una caverna fossilifera scoperta a Cucigliana Monti Pisani [On a fossiliferous cave discovered in Cucigliana Monti Pisani]. - Atti della Società toscana di scienze naturali, Memorie, 5: 109-166. (in Italian)

Berto, C., Rubinato, G. (2013): The upper Pleistocene mammal record from Caverna degli Orsi (San Dorligo della Valle - Dolina, Trieste, Italy): A faunal complex between eastern and western Europe. - Quaternary International, 284: 7-14. https://doi.org/10.1016/j.quaint.2011.07.025

Bertolini, M., Fedozzi, S., Martini, F., Sala, B. (1996): Late Glacial and Holocene climatic oscillations inferred from the variations in the micromammal associations at Grotta della Serratura (Marina di Camerota, Salerno, S. Italy). - Il Quaternario, Italian Journal of Quaternary Sciences, 9(2): 561-566.

Boschian, G. (1992): Una «Caverna ad Ursus» sul Carso Triestino: la Caverna degli Orsi presso S. Dorligo della Valle. Nota preliminare [A "Caverna ad Ursus" on the Carso Triestino: the Caverna degli Orsi near S. Dorligo della Valle. Preliminary note]. - Atti della Societa toscana di scienze naturali, Memorie, Serie A, 99: 153-159. (in Italian)

Boschian, G., Abbazzi, L., Gentili, S., Sala, B. (1996): The "Caverna degli Orsi": a cave bear site with lithic industry in the Trieste Karst (NE Italy). - In: Peretto, C. (ed.), Proceedings of the XIII Congress, International Union of Prehistoric and Protohistoric Sciences, vol. 2. A.B.A.C.O. Edizioni, Forlì, pp. 209-214.

Boschian, G., De Santis, A. (2011): Bears and sediments at Caverna degli Orsi/Medvedja jama (Trieste, Italy). - In: Toškan, B. (ed.), Fragments of Ice Age environments. Proceedings in Honour of Ivan Turk's Jubilee. Opera Intituti Archaelogici Sloveniae, 21: 181-207.

Cioni, O., Gambassini, P., Torre, D. (1980): Grotta di Castelcivita: risultati delle ricerche negli anni 1975-77 [Castelcivita Cave: results of research in the years 1975-77]. Atti della Società Toscana di Scienze Naturali, Memorie, Serie A, 86: 275-296. (in Italian)

Desclaux, E., Abbassi, M., Marquet, J.-C., Chaline, J., Van Kolfschoten, T. (2000): Distribution and evolution of Arvicola Lacépède, 1799 (Mammalia, Rodentia) in France and Liguria (Italy) during the Middle and the Upper Pleistocene. - Acta zoologica cracoviensia, 43(1-2): 107-125.
Falguères, C., Bahain, J. J., Tozzi, C., Boschian, G., Dolo, J.-M., Mercier, R., Valladas, H., Yokoyama, Y. (2008): ESR/U-series chronology of the Lower Palaeolithic palaeoanthropological site of Visogliano, Trieste, Italy. Quaternary Geochronology, 3: 390-398. https://doi.org/10.1016/j.quageo.2008.01.007

Farina, S. E. (2011): A Late Pleistocene mammals from Grotta Cucigliana (Monte Pisano, Italy). - Atti della Società toscana di scienze naturali, Memorie, Serie B, 118: 67-74.

Frahnert, S. (1991): Zur Variabilität der Schmelzbandbreiten rezenter Schermäuse, Arvicola terrestris (Rodentia, Mammalia), im zentralen Mitteleuropa. - Säugetierkundliche Informationen, 3: 235-247.

Gambassini, P. (ed.) (1997): Il Paleolitico di Castelcivita: culture e ambiente [The Paleolithic of Castelcivita: culture and environment] (series Materiae, vol. 5). - Electa, Napoli, 159 pp. (in Italian)

Heinrich, W.-D. (1981): Zur Evolution und Biostratigraphie von Arvicola (Rodentia, Mammalia) im Pleistozän Europas. - Zeitschrift für geologische Wissenschaften, 10(6): 683-735.

Heinrich, W.-D. (1987): Neue Ergebnisse zur Evolution und Biostratigraphie von Arvicola (Rodentia, Mammalia) im Quartär Europas. - Zeitschrift für geologische Wissenschaften, 15(3): 389-406.

Heinrich, W.-D. (1990): Review of fossil arvicolids (Mammalia, Rodentia) from the Pliocene and Quaternary in the German Democratic Republic. - In: Fejfar, O., Heinrich, W.-D. (eds), International Symposium Evolution, Phylogeny, Biostratigraphy of Arvicolids (Rodentia, Mammalia) in Rohanov, May 1987. Geological Survey, Verlag Dr. Friedrich Pfeil, Prague, Munich, pp. 183-200.

Heinrich, W.-D., Jánossy, D. (1977): Insektivoren und Rodentier aus dem Travertin von Taubach bei Weimar. Quartärpaläontologie, 2: 401-411.

Heinrich, W.-D., Maul, L. (1983): Skelettreste von Nagetieren (Rodentia, Mammalia) aus dem fossilen Tierbautensystem von Pisede bei Malchin. Teil. 1. Taxonomische und biometrische Kennzeichnung des Fundgutes. Wissenschaftliche Zeitschrift der Humboldt-Universität zu Berlin, Mathematisch-Naturwissenschaftliche Reihe, 32(6): 729-743.

Jánossy, D. (1975): Kleinsäugerfunde aus den Travertinen von Weimar-Ehringsdorf. - In: Kahlke, H.-D. (ed.), Das Pleistozän von Weimar-Ehringsdorf, Teil 2. Abhandlungen des Zentralen Geologischen Instituts, Paläontologische Abhandlungen, 23: 501-511.

Koenigswald, W. v. (1970): Mittelpleistozäne Kleinsäugerfauna aus der Spaltenfüllung Petersbuch bei Eichstätt. - Mitteilungen der Bayerischen Staatssammlung für Paläontologie und historische Geologie, 10: 407-432.

Koenigswald, W. v. (1973): Veränderungen in der Kleinsäugerfauna von Mitteleuropa zwischen Cromer und Eem (Pleistozän). - Eiszeitalter und Gegenwart, 23/24: 159167, $152 \mathrm{Abb}$. https://doi.org/10.3285/eg.23-24.1.14

Koenigswald, W. v., Van Kolfschoten, T. (1996). The Mimomys-Arvicola boundary and the enamel thickness quotient (SDQ) of Arvicola as stratigraphic markers in the Middle Pleistocene. - In: Turner, C. (ed.), The early 
Middle Pleistocene in Europe. A. A. Balkema, Rotterdam, pp. 211-226.

https://doi.org/10.1201/9781003077879-15

López-García, J. M., Berto, C., Colamussi, V., Dalla Valle, C., Lo Vetro, D., Luzi, E., Malavasi, G., Martini, F., Sala, B. (2014): Palaeoenvironmental and palaeoclimatic reconstruction of the latest Pleistocene-Holocene sequence from Grotta del Romito (Calabria, southern Italy) using the small-mammal assemblages. - Palaeogeography, Palaeoclimatology, Palaeoecology, 409: 169-179. https://doi.org/10.1016/j.palaeo.2014.05.017

Mania, D. (1983): Geologisch-geomorphologische Untersuchungen zur Ökologie des Homo erectus von Bilzingsleben. - In: Mai, D. H., Mania, D., Nötzold, T., Toepfer, V., Heinrich, W.-D. (eds), Bilzingsleben II. Homo erectus seine Kultur und seine Umwelt. Veröffentlichungen des Landesmuseums für Vorgeschichte in Halle, 36: 23-39.

Mania, D. (1997): Das Quartär des Saalegebietes und des Harzvorlandes unter besonderer Berücksichtigung der Travertine von Bilzingsleben - Ein Beitrag zur zyklischen Gliederung des eurasischen Quartärs. - In: Mania, D., Mania, U., Heinrich, W.-D., Fischer, K.-H., Böhme, G., Turner, A., Erd, K., Mai, D. H. (eds), Bilzingsleben V. Homo erectus - seine Kultur und seine Umwelt. Ausbildung + Wissen, Bad Homburg, Leipzig, pp. 23-104.

Masini, F., Abbazzi, L. (1997): L'associazione di mammiferi della Grotta di Castelcivita [The mammal assemblage of the Castelcivita Cave]. - In: Gambassini, P. (ed.), Il Paleolitico di Castelcivita: culture e ambiente [The Paleolithic of Castelcivita: culture and environment] (series Materiae, vol. 5). Electa, Napoli, pp. 33-59. (in Italian)

Maul, L. C. (1994): Oberpleistozäne Einwanderung von Hystrix nach Mitteleuropa. - Zeitschrift für Säugetierkunde, 59(Sonderheft): 30.

Maul, L. C., Masini, F., Abbazzi, L., Turner, A. (1998): The use of different morphometric data for absolute age calibration of some South and Middle European arvicolid populations. - Palaeontographia Italica, 85: 111-151.

Maul, L. C., Parfitt, S. A. (2010): Micromammals from the 1995 Mammoth Excavation at West Runton, Norfolk, UK: Morphometric data, biostratigraphy and taxonomic reappraisal. - Quaternary International, 228: 91-115. https://doi.org/10.1016/j.quaint.2009.01.005

Maul, L. C., Rekovets, L. I., Heinrich, W.-D., Keller, T., Storch, G. (2000): Arvicola mosbachensis (Schmidtgen 1911) of Mosbach 2: a basic sample for the early evolution of the genus and a reference for further biostratigraphical studies. - Senckenbergiana lethaea, 80(1): 129-147.

https://doi.org/10.1007/BF03043667
Mazza, P. P. A., Martini, F., Sala, B., Magi, M., Colombini, M. P., Giachi, G., Landucci, F., Lemorini, C., Modugno, F., Ribechini, E. (2006): A new Palaeolithic discovery: tar-hafted stone tools in a European Mid-Pleistocene bone-bearing bed. - Journal of Archaeological Science, 33: $1810-1818$. https://doi.org/10.1016/j.jas.2006.01.006

Ronchitelli, A. (1998): Structures d'habitat dans la Grotta Grande de Scario (S. Giovanni a Piro, Salerno-Italie). - In: Proceedings of the XIII Congress, International Union of Prehistoric and Protohistoric Sciences, vol. 2. A.B.A.C.O. Edizioni, Forlì, pp. 153-163. [p. 157: Abbazzi, L., Masini, F.: L'association faunistique du sondage 'F'a la Grotta Grande de Scario].

Ronchitelli, A., Boscato, P., Surdi, G., Masini, F., Petruso, D., Accorsi, C. A., Torri, P. (2011): The Grotta Grande of Scario (Salerno, Italy): Archaeology and environment during the last interglacial (MIS 5) of the Mediterranean region. - Quaternary International, 231: 95-109.

https://doi.org/10.1016/j.quaint.2010.07.006

Sala, B. (1996): Gli animali del giacimento di Isernia La Pineta [The animals of the Isernia La Pineta site]. - In: Peretto, C. (ed.), I reperti paleontologici del giacimento Paleolitico di Isernia La Pineta [Palaeontological finds of the Paleolithic deposit of Isernia La Pineta]. Cosmo Iannone Editore, Isernia, pp. 25-49. (in Italian)

Van Kolfschoten, T. (1990): The evolution of the mammal fauna in The Netherlands and the middle Rhine Area (Western Germany) during the late Middle Pleistocene. - Mededelingen Rijks Geologische Dienst, 43: 1-69.

Vlček, E., Mania, D., Mania, U., (2002): Bilzingsleben VI - Der fossile Mensch von Bilzingsleben. - Beier und Beran, Weissbach, 392 pp.

Wagner, G. A., Krbetschek, M., Degering, D., Bahain, J.-J., Shao, Q., Falguères, C., Voinchet, P., Dolo, J.-M., Garcia, T., Rightmire, G. P. (2010): Radiometric dating of the type-site for Homo heidelbergensis at Mauer, Germany. - Proceedings of the National Academy of Sciences, 107(46): 19726-19730. https://doi.org/10.1073/pnas.1012722107

Wagner, G. A., Maul, L. C., Löscher, M., Schreiber, H. D. (2011): Mauer - the type site of Homo heidelbergensis: Palaeoenvironment and age. - Quaternary Science Reviews, 30: 1464-1473. https://doi.org/10.1016/j.quascirev.2010.01.013

Wiegank, F. (1997): Paläomagnetische Charakteristik des Unterpleistozäns von Untermaßfeld. - In: Kahlke, R.-D. (ed.), Das Pleistozän von Untermassfeld bei Meiningen (Thüringen). Teil 1. Monographien, Römisch-Germanisches Zentralmuseum, 40(1): 63-69. 


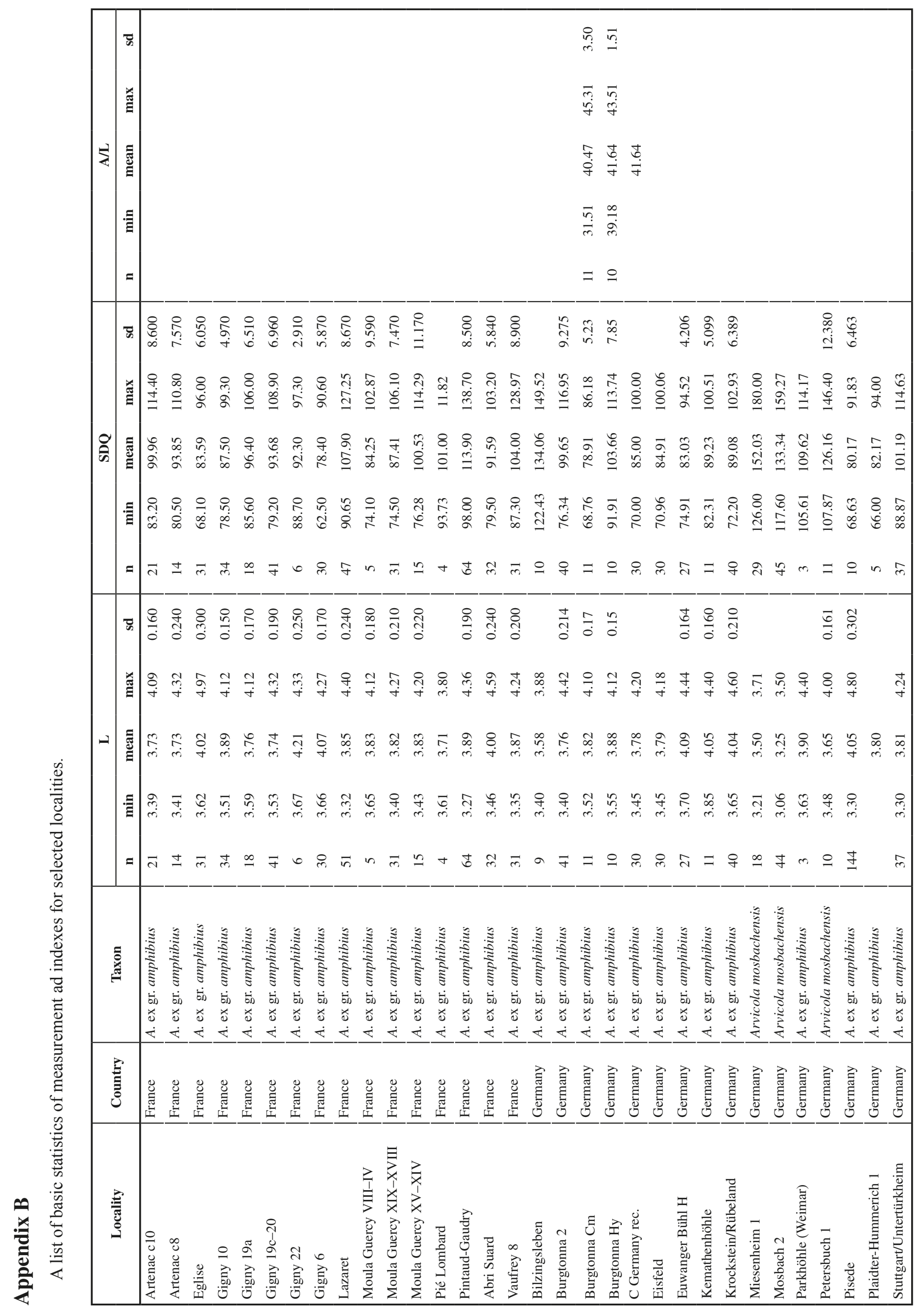




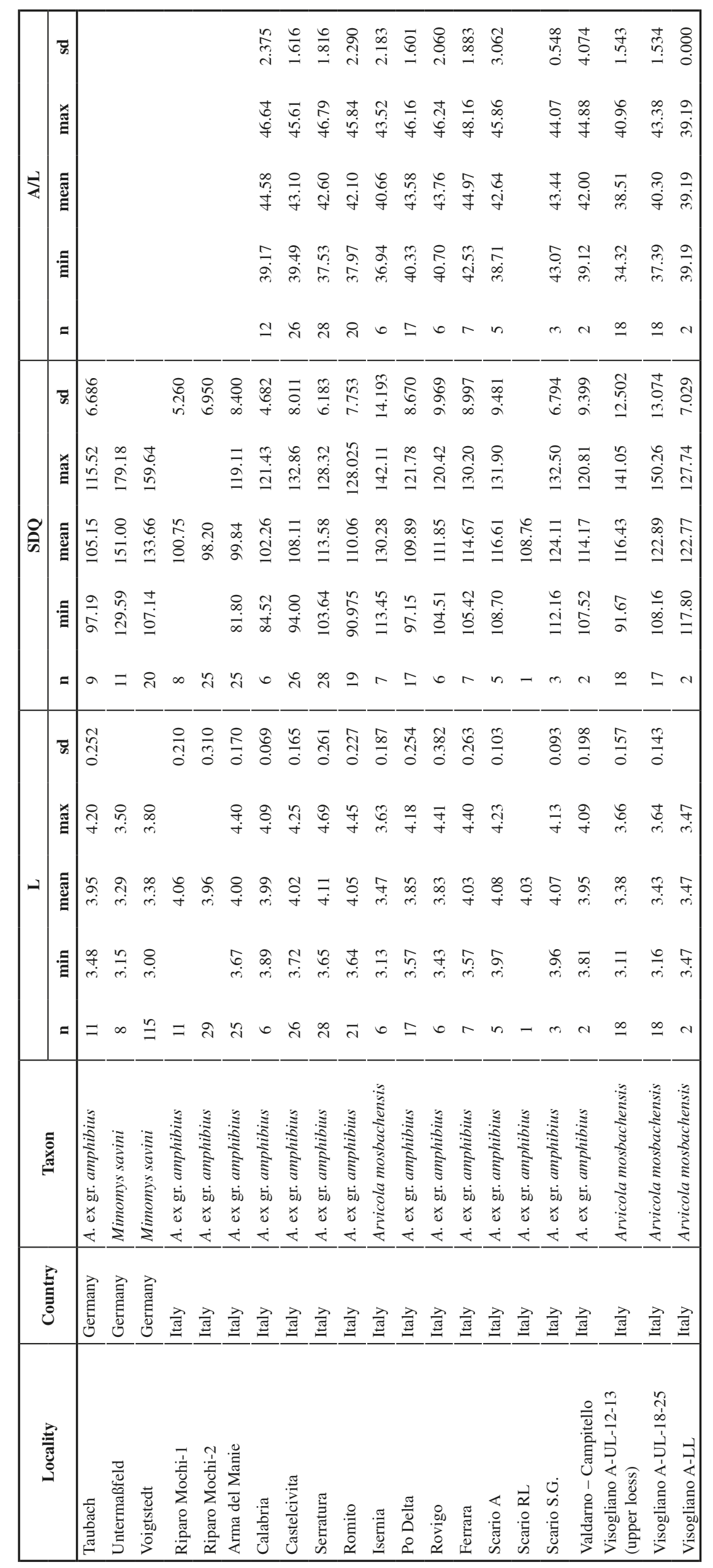

